\title{
Finite element modeling of neotectonics in New Zealand
}

\author{
Zhen Liu and Peter Bird \\ Department of Earth and Space Sciences, University of California, Los Angeles, California, USA
}

Received 14 August 2001; revised 19 May 2002; accepted 12 August 2002; published 6 December 2002.

[1] Thin-shell finite element methods that incorporate faults, realistic rheology, laterally varying heat flow and topography, and plate velocity boundary conditions have been used to model the neotectonics of New Zealand. We find that New Zealand's faults have effective friction of $\sim 0.17$, comparable to that found in other Pacific Rim regions. The long-term average slip rate of the Alpine fault varies along strike, generally increasing northeastward until slip is partitioned among the strands of the Marlborough system. The average slip rate, $\sim 30 \mathrm{~mm} / \mathrm{yr}$, when combined with published geodetic results and historical seismicity, strongly suggests a high probability of future large earthquakes. Tectonic deformation of North Island is controlled by a balance between differential topographic pressure and traction from the Hikurangi subduction thrust. The Hikurangi forearc is an independent plate sliver moving relative to the Pacific and Australian plates. There is a complicated zone of slip partitioning in the transition from the Alpine fault to the Puysegur trench. An offshore thrust fault, the southern segment of which may correspond to the Waipounamou fault system, parallels to the SE coast of South Island and needs to be included in seismic hazard estimates. INDEX TERMS: 8107 Tectonophysics: Continental neotectonics; 8120 Tectonophysics: Dynamics of lithosphere and mantle - general; 8164 Tectonophysics: Evolution of the Earth: Stresses - crust and lithosphere; 9355 Information Related to Geographic Region: Pacific Ocean; 3040 Marine Geology and Geophysics: Plate tectonics (8150, 8155, 8157, 8158); 3025 Marine Geology and Geophysics: Marine seismics (0935); 0930 Exploration Geophysics: Oceanic structures; KEYWORDS: New Zealand, neotectonics, finite element, Alpine fault, seismic hazard, tectonic deformation

Citation: Liu, Z., and P. Bird, Finite element modeling of neotectonics in New Zealand, J. Geophys. Res., 107(B12), 2328, doi:10.1029/2001JB001075, 2002.

\section{Introduction}

[2] As shown in Figure 1, New Zealand is a part of a "continental" plateau that includes the Chatham Rise and Campbell Plateau to the east, and the Challenger Rise-Lord Howe Rise to the west. Its neotectonic elements include two subduction zones (Hikurangi and Puysegur), a dextral strike-slip fault system (Marlborough faults), a transpressional plate boundary fault (Alpine fault), a young mountain range (Southern Alps) formed by continental convergence, and two transitions between oceanic subduction and oblique continental convergence. This diversity makes New Zealand one of the best places to study plate boundary deformation.

[3] One important problem in the neotectonics of New Zealand is how the plate motion is accommodated in each of the different tectonic regimes across the country. Advances in Global Positioning System (GPS) geodesy, seismic determination of crustal structure, seismic catalogs, seismic anisotropy and tomography suggest many complexities [Beavan et al., 1999; Beavan and Haines, 2001; Melhuish et al., 1999; Reyners et al., 1997; Anderson et al., 1993; Marson-Pidgeon et al., 1999; Molnar et al., 1999; Stern et al., 2000]. The transition zone between southern North

Copyright 2002 by the American Geophysical Union. 0148-0227/02/2001JB001075\$09.00
Island and northern South Island has provoked controversy about relative velocity partitioning between fault slip in the onshore back arc region [Beanland, 1995], interplate thrusting, and offshore faulting [Barnes et al., 1998]. In the Marlborough fault system, Yang [1991] argued that slip rates sum to $38 \mathrm{~mm} / \mathrm{yr}$, which implies $\sim 20 \%$ of the relative plate movement is expressed as distributed deformation in northern South Island. However, kinematic modeling shows that known faults of the Marlborough region could accommodate $100 \%$ of relative plate motion [Holt and Haines, 1995]. Various tectonic styles have been suggested to operate in this region, e.g., crustal block rotation [Walcott et al., 1981; Lamb and Bibby, 1989; Vickery and Lamb, 1995], crustal blocks driven by upper mantle flow [Bourne et al., 1998], distributed continuous mantle lithosphere deformation [Molnar et al., 1999], an undiscovered buried blind fault [Van Dissen and Yeats, 1991], and diffuse deformation to the east of the Marlborough fault system. In central South Island, there is disagreement about the fate of excess continental crust resulting from convergence. A lateral extrusion of the lower crust [Walcott, 1998], thickened crustal uplift and erosion [Wellman, 1979], and collapse of thickened continental lithosphere (M. Kohler, personal communication, 1999) are suggested being active in this region. Molnar et al. [1999] argued that distributed shear deformation in the mantle lithosphere has occurred 


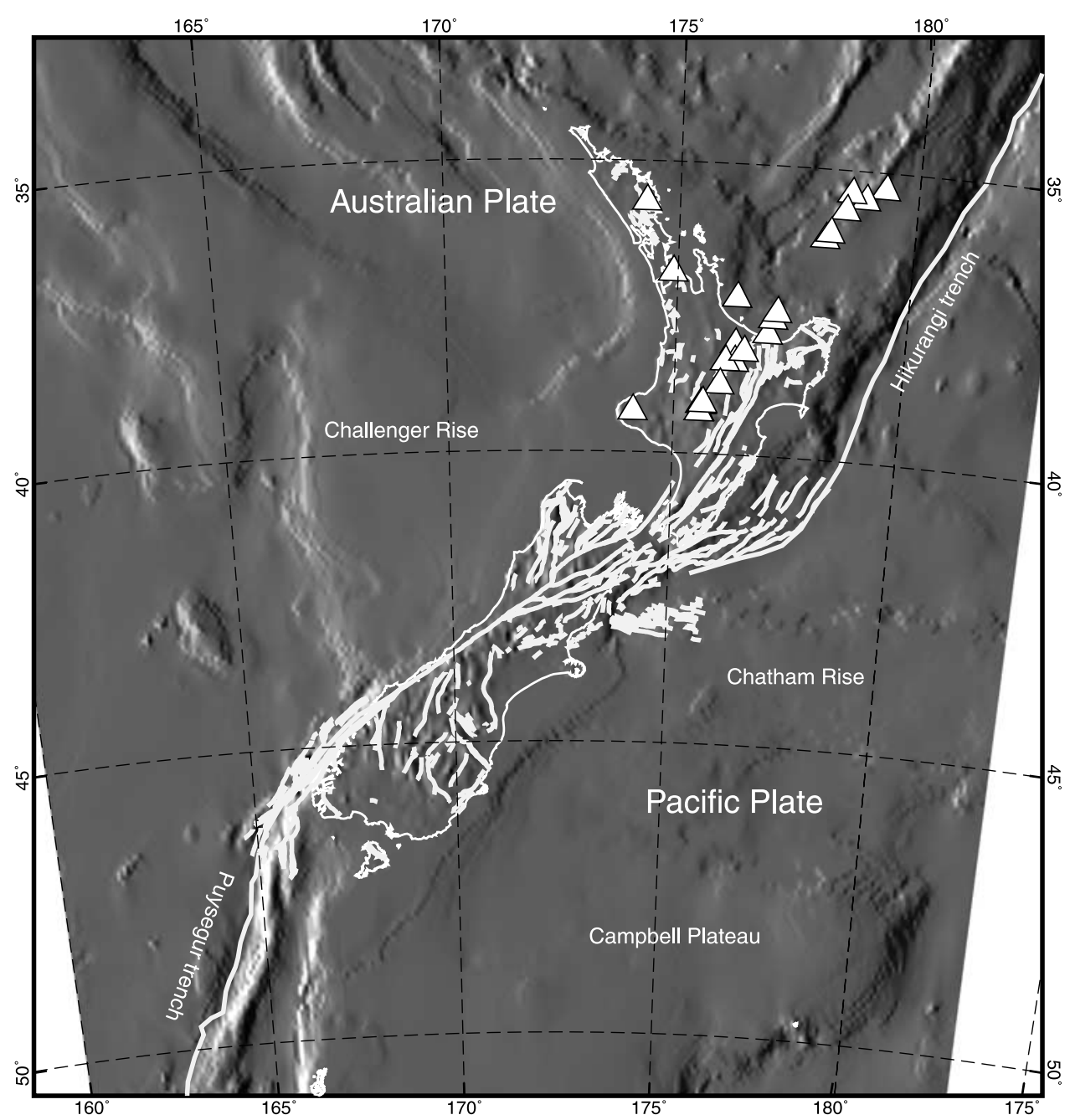

Figure 1. Tectonic environment of New Zealand. Lambert conformal conic projection. Major tectonic elements are labeled. White lines represent active and potentially active fault traces. Triangles represent active volcanoes overlying shaded-relief topography (colorful representation is in HTML online version). The hypothesized northwestern and southeastern faults offshore South Island are not shown in this figure; compare to Figure 3.

beneath South Island based on uniformly oriented shear wave splitting directions. South of South Island, most convergence during the Pliocene-Quaternary involved subducting oceanic lithosphere of the Australia plate under the Fiordland block [Walcott, 1998]. Recent bathymetry and seismic refraction studies reveal complicated transitional faults connecting the Alpine fault to the Puysegur subduction zone. This finding undermines the long-held view that the strike-slip southern segment of the Alpine fault abruptly changes into Puysegur subduction thrusting [Lebrun et al., 2000]. The complex transition fault geometry indicates more complicated slip partitioning and, potentially, strain distribution east of the fault zone. Clearly, finite element models that include faults can help us predict how strain might be distributed across the island and test various proposed kinematic models for dynamic plausibility.

[4] Similarities have been noted between faults in New Zealand and those in southern California [Yeats and Berryman, 1985]. However, historical seismicity from 1840 to 1999 does not show any apparent spatial correlation with active faults in New Zealand (T. Webb, personal communication, 2000). There is some evidence that New Zealand's faults may be weak (with low friction, or low effective friction due to high pore pressure). For example, principal horizontal shortening directions derived from active faulting [Berryman, 1979] and principal stress directions derived from mesoscale structures [Pettinga and Wise, 1994] shows high angles between the most compressive horizontal principal stress direction $\hat{\sigma}_{1 \mathrm{~h}}$ and some strike-slip faults. Such angles indicate low shear stress in these faults. The transition from extension in central North Island to subparallel thrusting in the Hikurangi subduction zone takes place across a topographic relief of no more than $4 \mathrm{~km}$. This suggests that effective friction in normal faults of the Central Volcanic Region (CVR)/Taupo Volcanic Zone (TVZ) is low. However, no quantitative study has been completed, and it is not clear if all active faults in New Zealand have similar low effective friction, as we find in other areas [Bird and Kong, 1994; Kong, 1995; Bird, 1996, 1998]. 
[5] What dynamic balance controls the velocity of the Hikurangi forearc, which seems to move independently of its two bounding plates? Inverse kinematic models have shown that active CVR/TVZ extension is necessary to match the velocities observed in North Island [Beanland and Haines, 1998]. GPS observations indicate that asymmetric extension occurs in the CVR/TVZ and that the Hikurangi forearc moves at about $14-20 \mathrm{~mm} / \mathrm{yr}$ relative to AU [Beavan and Haines, 2001]. It is also unclear whether possible offshore extensions of the CVR/TVZ are active at comparable rates. Recent study of the offshore Whakatane graben shows complex fault segmentation in a northward continuation of the North Island Dextral Fault Belt (NIDFB) as well as offshore divergence and termination of NE-trending normal faults that bound the CVR/TVZ [Lamarche et al., 2000]. Intense seismicity, active extension, high heat flow, and volcanoes (White Island) indicate that the CVR/TVZ extends offshore to the NNE, possibly all the way to the Lau-Havre Trough back arc spreading center. A comprehensive dynamic model that includes heat flow and topography variations, faults and subduction thrust traction helps us better understand the tectonics in this region. We also test the hypothesis that the Hikurangi forearc acts as an independent plate sliver moving relative to Australia and Pacific plates, as previously suggested by a kinematic study [Wellman and Uyeda, 1983] and a GPSderived New Zealand velocity model [Beavan and Haines, 2001].

[6] The Alpine fault extends $\sim 500 \mathrm{~km}$ and has asymmetric uplift and deformation along its strike, with significant variations in structure, slip rate, dip, seismicity, and crust and upper mantle structure [Norris et al., 1990; Norris and Cooper, 1995; Berryman et al., 1992; Stirling et al., 1998; Anderson et al., 1993; Beavan et al., 1999]. The central part of this fault has a significant reverse (or thrust) component and a SE dip. The likelihood of large earthquakes on the central Alpine fault has been controversial. Exceptionally high heat flow and a very shallow brittleductile transition prompt doubt about the ability of this fault to accumulate elastic strain [Walcott, 1998]. However, historical seismicity reveals that this fault was not always seismically inactive; paleoseismicity studies show that major earthquakes have occurred at irregular intervals in the past 600 years [Wells et al., 1999]. Clearly long-term slip rates for the Alpine fault will be helpful for estimating seismic hazard. Seismic studies and recent GPS results suggest that the inferred long-term slip rate on the central Alpine fault is sensitive to the fault's dip [Davey et al., 1995, 1998; Beavan et al., 1999]. This makes it necessary to clarify the dip.

[7] The bathymetric contours offshore southeastern and northwestern South Island are suspiciously straight, suggesting possible control by fault scarps. On the NW, there have been a few earthquakes with magnitude $\geq 5.0$ well to the NW of the Alpine fault. On the SE, a few events M4+ occurred near Dunedin and offshore. It is not clear whether the NW and SE coasts of South Island are bounded by active thrust faults, or whether these straight continental shelf edges are simply smoothed by strong ocean currents. If active thrust faults crop out offshore and causes large earthquakes below the coastline, it would be prudent to include them in seismic hazard estimates.
[8] Numerous models of the neotectonics of various parts of New Zealand have been put forward. These include a bending beam model [Merzer and Freund, 1974], a modified beam model [Anderson et al., 1993], block-kinematic models [Lamb and Bibby, 1989], inverse kinematic models [Holt and Haines, 1995; Beanland and Haines, 1998], 2-D cross-section models [Beaumont et al., 1996; Koons, 1990], 3-D "sandbox" models [Koons and Henderson, 1995], and 3-D finite element models [Braun and Beaumont, 1995]. Most do not incorporate realistic rheology or faults or solve the momentum equation. In contrast, 2-D plane-strain and 3-D models by the Beaumont group [Beaumont et al., 1994, 1996; Braun and Beaumont, 1995] are more realistic. However, they impose kinematic boundary conditions at the base of the crust, which probably determines the deformation mode of tectonic wedging (reversal of subduction dip at depth). Other possible modes of orogeny may have been suppressed. Other models deal with thermal evolution of the central Alps region [Shi et al., 1996], thermally coupled dynamics of the central collision zone [Batt and Braun, 1999] and of erosional control of the asymmetric structure of the orogen [Willett, 1999]. Those models use 2-D cross sections and simplified boundary conditions. Can 2-D plane-strain give a realistic approximation of the highly oblique collision in the central South Island?

[9] Here we apply the thin-shell finite element method to model neotectonic deformation of New Zealand. Our goal is to build regional models that are as realistic as possible, including actual fault networks, stresses from topography and its compensation, and a realistic thermally activated, nonlinear rheology for the crust and mantle lithosphere. Different tectonic regimes across New Zealand are incorporated into one model using consistent assumptions. Forward modeling experiments are used to test hypotheses concerning neotectonics. The comparison of predictions from our models with available geological and geophysical observations allow us to select a preferred model, which gives an overview of neotectonic deformation in New Zealand and predicts long-term slip rates for all active faults.

\section{Theory and Method}

[10] The thin-shell finite element code SHELLS is applied. More detailed descriptions of SHELLS are given by Kong [1995] and Bird [1999]. Here we describe the basic methods and approximations.

[11] The thin-shell method leads to a forward dynamic model in which stress equilibrium and conservation of mass are solved with presumed rheologies and densities. As a result, long-term velocities, strain rates, and stresses are predicted and can be tested against independent measurements such as geologically determined fault slip rates, stress directions. After a correction for elastic strain rates due to temporary fault locking, these models can also be compared quantitatively to relative velocities from GPS.

[12] Because the thin-shell method uses spherical triangular elements it can model spherical lithospheric shells with high accuracy. The method incorporates thermally activated nonlinear dislocation creep in the lower crust and mantle and Mohr-Coulomb frictional plasticity in the shallow parts of crust and upper mantle. It also includes faults and laterally varying topography, heat flow, and crust 
and mantle lithosphere thickness. Even though the velocity model is 2-D (horizontal components are independent of depth), SHELLS solves the momentum equation in a vertically integrated form, using a 3-D model of plate strength and density; thus it has some 3-D features. In this sense, it has been called a " 2.5 -D finite element method." We use the following assumptions and approximations:

1. Quasi steady state. The inertia term of the momentum equation is ignored. The timescale for velocity averaging is larger than the length of one earthquake cycle.

2. Anelastic rheology. Elastic strain is neglected, to avoid arbitrary initial conditions and time steps. (Estimated elastic strain rates can be added in a postprocessing step.)

3. No vertical shear traction is considered on vertical planes. It is assumed that vertical normal stress is lithostatic at all points. Thus we ignore flexural strength.

4. Thin-shell approximations. Only horizontal components of the momentum equation are integrated across the plate and solved. The vertical component is replaced by the isostatic approximation.

5. No lateral variation of thermal properties. Constant but distinct heat productivity and conductivity are assumed for the crust and upper mantle.

6. Incompressibility.

7. Vertical steady state heat conduction. The bottom of lithosphere is assumed to be an isothermal surface $\left(\sim 1200^{\circ}\right)$. Crust and mantle lithosphere thicknesses are obtained by jointly solving steady state heat conduction and isostatic equilibrium equations.

\section{Model Construction}

[13] Three types of data are used to construct models: topography, heat flow and traces and dips of active (or potentially active) faults.

\subsection{Topography and Heat Flow}

[14] Topography is from the ETOPO5 global topography data set with $5^{\prime} \times 5^{\prime}$ resolution. No complete heat flow map is available for New Zealand. We compiled 277 heat flow measurements from published sources [Studt and Thompson, 1969; Pandey, 1981; Townend, 1997, 1999; Funnell et al., 1996], but these heat flow data are not evenly distributed. Heat flow data are also inconsistent at certain points, possibly because of groundwater convection and volcanism. In order to deal with this incomplete and nonideal data set, we tried two approaches:

[15] First, we created some models with uniform heat flow for the whole region. (While not realistic, such models allow us to check which features of the solutions are independent of the lateral heat flow gradients that are assumed in more realistic models). Histogram analysis shows that average heat flow is $76 \pm 15 \mathrm{~mW} / \mathrm{m}^{2}$ along the west coast of South Island, and $67 \pm 35 \mathrm{~mW} / \mathrm{m}^{2}$ in North Island. We took $70 \mathrm{~mW} / \mathrm{m}^{2}$ as the uniform heat flow value for New Zealand.

[16] Second, we drew a "predicted heat flow" map combining all available heat flow data, seismic crust and mantle structure, thermal modeling results [Allis and Shi, 1995; Shi et al., 1996], uplift and erosion maps [Wellman, 1979] and seismicity depths. In model groups 1, 3, and 4, nonuniform heat flow for the CVR/TVZ was assumed to be
$90 \mathrm{~mW} / \mathrm{m}^{2}$ and the CVR/TVZ was limited to onshore areas. Later we varied these assumptions as described below. Stern and Davey [1987] show thin crust $(\sim 15 \pm 2 \mathrm{~km})$ and low crustal and upper mantle seismic velocities beneath the CVR, which are consistent with high heat flow, active volcanism and back arc extension. But the heat flow he inferred (up to $\sim 700 \mathrm{~mW} / \mathrm{m}^{2}$ ) within the CVR/TVZ is likely due to strong circulation of hot groundwater. Such strong fluid convection is probably limited to depths less than $8 \mathrm{~km}$. Below the convective systems the heat flow is dominated by conduction; rough estimation indicates the maximum conductive heat flow of this area is only $\sim 400$ $\mathrm{mW} / \mathrm{m}^{2}$ [Bibby et al., 1995]. More recent studies show the highest heat flow is confined to the Taupo Volcanic Zone, which is approximately the eastern half of the Central Volcanic Region [Wilson et al., 1995; Bibby et al., 1995]. In our final model group 7 , we limited heat flow to $\sim 400$ $\mathrm{mW} / \mathrm{m}^{2}$ and concentrated the high heat flow in the Taupo Volcanic Zone. Figure 2 shows the nonuniform heat flow map used in this final model group 7.

\subsection{Faults in New Zealand}

[17] Onshore fault traces were digitized from the map by New Zealand Geological Survey [1972]. Offshore traces are given by Barnes et al. [1998]. The transitional fault traces between the strike-slip southern segment of the Alpine fault and the oblique Puysegur subduction fault are given by Lebrun et al. [2000]. Fault dips are from an active fault compilation by Stirling et al. [1998]. We do not assume that major dextral faults of the Marlborough fault system can be linked directly to dextral faults in North Island as suggested by Lensen [1958]. Seismic reflection reveals that Cook Strait is a structural discontinuity trending roughly WNW-ESE with dextral steps between traces. None of the major faults reaching Cook Strait can be traced to connect continuously across it [Carter et al., 1988]. Thus fault elements are not connected across Cook Strait in our finite element models. Figure 3 shows the model mesh and fault elements used.

\subsection{Applied Plate Motion}

[18] We use the NUVEL-1A model to compute relative Pacific-Australia (PA-AU) plate velocities [DeMets et al., 1994] for most models. The reference frame is Australia fixed. The southeastern side of the grid, extending from the Hikurangi subduction zone to the Puysegur oblique subduction zone, is given velocity boundary conditions calculated using Euler vector $\left(-60.1^{\circ} \mathrm{N},-178.3^{\circ} \mathrm{E}, 1.07^{\circ} / \mathrm{Ma}\right)$. Later we will show that the northeastern boundary condition on the Hikurangi forearc has significant effects on tectonic deformation in central North Island and is more complicated than we initially expected. We have tried different boundary conditions on this part.

\subsection{Lithosphere Structure of New Zealand}

[19] The lithosphere structure of New Zealand is difficult to estimate. No complete maps of crust and upper mantle structure have been published. We use topography and the current conductive heat flow map (uniform model, or model of Figure 2) to infer crust and upper mantle lithosphere thicknesses for each model under assumptions of steady state and isostasy. We compared the crust and mantle lithosphere thickness inferred from the nonuniform heat 


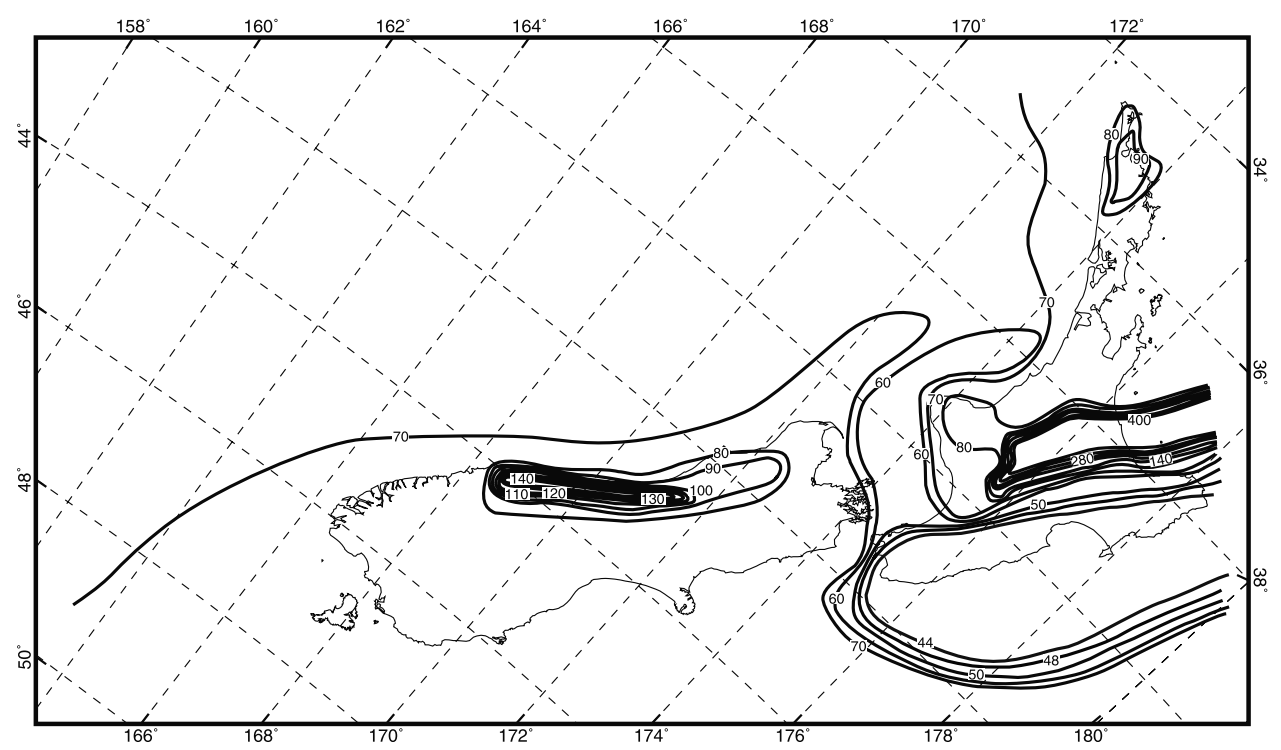

Figure 2. Contours of nonuniform heat flow map used in the final model group 7. Mercator projection. Unit of contour label is $\mathrm{mW} / \mathrm{m}^{2}$. Exceptionally high heat flow is concentrated in the Taupo Volcanic Zone and assumed to be $\sim 400 \mathrm{~mW} / \mathrm{m}^{2}$. High heat flow in the Southern Alps is caused primarily by extremely high erosion rates. HTML online version shows nonuniform heat flow map in color.

flow map with published seismic structures, e.g., the crustal structure of the Puysegur oblique subduction zone [Melhuish et al., 1999], crustal structure for the CVR/TVZ [Stern and Davey, 1987; Smith et al., 1989] and central South Island [Kleffmann et al., 1998], and crust structure of the
Hikurangi subduction zone [Reyners, 1998]. Generally they are in good agreement except that our model gives anomalously large crust and mantle lithosphere thickness in the Hikurangi forearc region. These result from low heat flow $\left(\sim 44 \mathrm{~mW} / \mathrm{m}^{2}\right)$ and are an artifact of our thermal model,

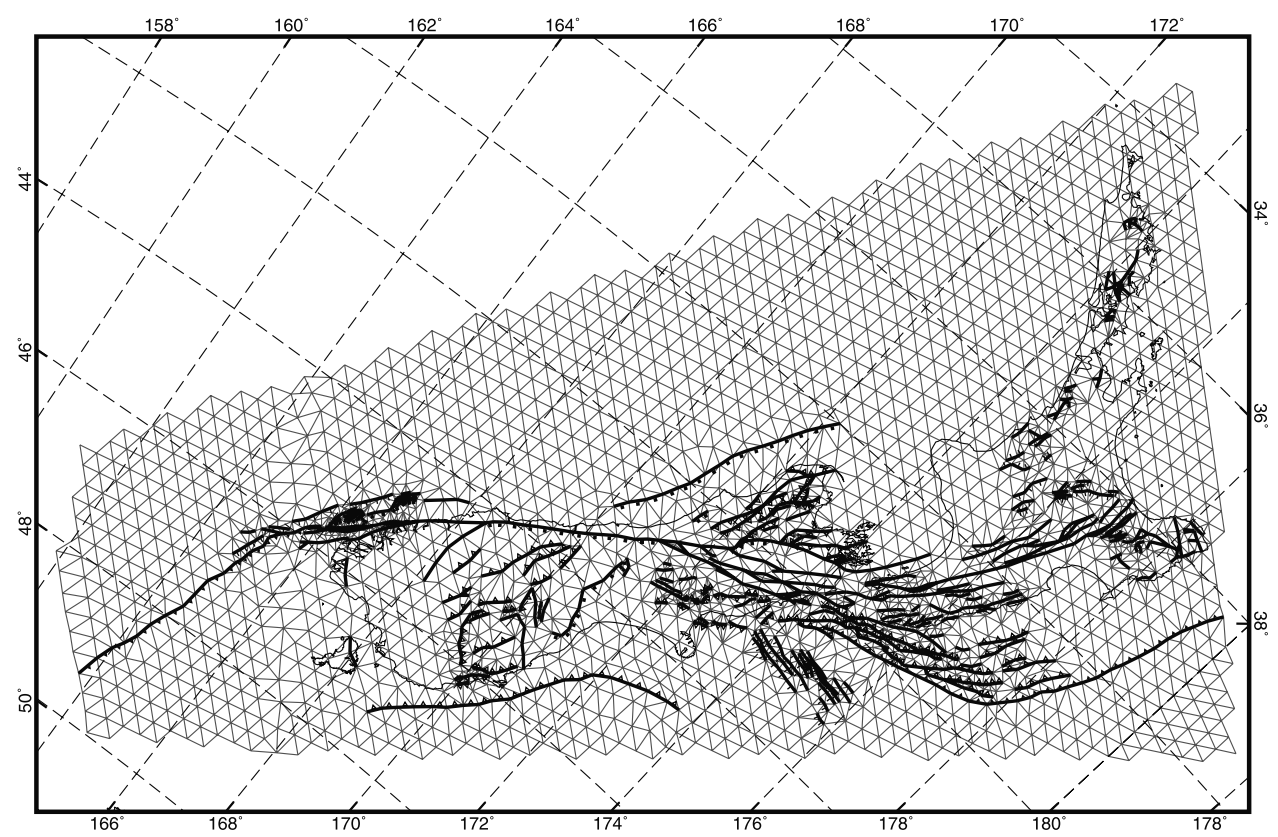

Figure 3. A typical finite element grid used in neotectonic modeling of New Zealand. Mercator projection. Thin lines and thick lines represent continuum elements and fault elements, respectively. Symbols on the fault traces represent fault type: open triangle, thrust fault; solid triangle, subduction thrust fault; solid square, fault with dip angle $45^{\circ}$; short line, normal fault. Faults without symbols attached are strike-slip faults. Fault dips are assigned: $90^{\circ}$ (for strike-slip fault), $65^{\circ}$ (for normal fault), $30^{\circ}$ (for thrust fault), and $25^{\circ}$ (for subduction thrust fault). Subduction thrust fault is subject to a limit (Taumax) on the downdip integral of shear traction. All faults including hypothesized NW and SE coastal faults offshore South Island are shown. 
which considers steady state thermal conduction but not subduction-induced advection.

\section{Scoring Data and Method}

[20] We used three types of data to test and score the predictions of our dynamic models: GPS observations, geological slip rates, stress directions.

\subsection{GPS Data}

[21] GPS observations from the central Southern Alps [Beavan et al., 1999] and 31 first-order GPS solutions [Beavan and Haines, 2001] were used to score the contemporary velocity fields predicted from each of the dynamic models. Velocity discontinuities across faults exist in the predicted long-term average velocities, but not in most geodetic measurements close to active faults. Such differences arise because geodetic measurements are obtained over short time periods during which there is temporary fault locking causing elastic strain accumulation around the faults, whereas our predicted velocity fields are long-term averages [Lisowski et al., 1991]. Following Savage's [1983] method, we treat interseismic strain accumulation as caused by steady slip of only the deep fault plane, from its subsurface locking depth to infinite depth. Since our predicted long-term average velocities result from steady slip on the entire fault plane from surface to infinite depth, dislocation-in-elastic-half-space corrections are used to simulate temporary locking of brittle part of faults before the scoring. The model depth of the brittle/ductile transition is calculated for each fault segment (and independently for each dynamic model) assuming that the dominant rheology at each depth point is that which gives the lower shear stress at that point. The brittle part of each fault segment is divided into a series of rectangular dislocation patches extending from the surface down to the brittle/ductile transition depth. The elastic dislocation-rate vectors in the brittle part of each fault patch are just the negatives of the slip rates predicted by the particular finite element model. Then the predicted interseismic GPS benchmark velocities are obtained by addition of the elastic dislocation corrections to our predicted long-term average velocities. That is, we make the comparison between geodesy and models in the shorttimescale domain of the geodetic data, rather than in the long-timescale domain of the models.

[22] There is some evidence for fractional coupling on the southern Hikurangi subduction thrust beneath Wellington [Darby and Beavan, 2000]. We have not considered this; for purposes of the elastic correction our model faults are all uniformly locked (coupled) down to a brittle/ductile transition in the crust (and possibly from the Moho to a second brittle/ductile transition in the mantle lithosphere), and then uniformly uncoupled (creeping) at greater depths. By considering only variations in locking depth, we avoid adding any free parameters in our elastic correction step. We begin with this simple method since coupling on most faults of New Zealand is not known. An improved correction may be attempted when we know more about the coupling, especially the gradual slip transition that may occur around the brittle/ductile transition depth.

[23] We have used AU-fixed reference frames for both predicted velocities and GPS measurements. Slight misfits remain because of different definitions of the AU frame. Reference frame adjustment is necessary to reduce these misalignment errors before final comparison of predicted velocities and GPS measurements. We calculated these adjustments by rigidly rotating predicted velocities to fit geodetic velocities on the sphere using a least squares criterion. Then the reference frame adjustment velocity for each station is added to the predicted velocity of that station to remove any relative rotation.

\subsection{Geological Slip Rates}

[24] We have compiled 33 slip rate measurements in the localities of the Alpine fault and Marlborough fault system from published sources [Knuepfer, 1988, 1992; Cowan, 1989; Van Dissen, 1989, 1991; Yang, 1991; Little et al., 1998; Wellman and Uyeda, 1983; Lamb and Bibby, 1989; Yetton and Nobes, 1998; Walcott, 1998; Sutherland, 1994; Cooper and Norris, 1994; Stirling et al., 1998; Sutherland and Norris, 1995]. Slip rates estimated for the North Island Dextral Fault Belt (NIDFB) and the faults offshore North Island [Beanland, 1995; Barnes et al., 1998] are used as references for discussion instead of scoring data because they have comparatively fewer published sources and larger uncertainties. To allow for large uncertainties in the determination of offsets or ages, certain criteria are used in our compilation of data. If various papers give compatible rate ranges for the same fault, the overlap (or consensus) rate range is used. If slip rate estimates for the same locality from various papers conflict, each is incorporated individually into the scoring process. The upper and lower bounds on slip rate at each site are obtained by dividing maximum offset by minimum age, and minimum offset by maximum age, respectively. Offsets with estimated ages $<\sim 2000$ years are not used to infer slip rate as they are likely to reflect fluctuations due to earthquake cycles. Prediction errors of a particular finite element model are defined as the discrepancy with respect to the nearer (upper or lower) limit on slip rate, not with respect to an average or "best estimate."

\subsection{Stress Direction}

[25] No published stress directions are available in New Zealand. We use compressive axis (P) azimuths from focal mechanism solutions of the Harvard Centroid Moment Tensor (CMT) catalog as approximations of $\hat{\sigma}_{1 \mathrm{~h}}$. A total of 362 earthquakes with $\mathrm{m}_{\mathrm{w}} \geq 5.7$ and focal depth $<60 \mathrm{~km}$ have been chosen.

[26] The incomplete, nonuniform coverage of the scoring data makes it understandable that different scoring data sets show preferences for different models. Therefore, we define the following formula to combine them together.

$$
\varepsilon=\frac{\left(\frac{\left(\varepsilon_{\text {stress }}-17^{\circ}\right)}{2^{\circ}} m m a^{-1}+\varepsilon_{\text {geodetic }}+\varepsilon_{\text {sliprate }}\right)}{3}
$$

where $\varepsilon_{\text {stress }}$ is the mean error of stress directions, and $\varepsilon_{\text {geodetic }}, \varepsilon_{\text {sliprate }}$ are the RMS errors of geodesy and slip rates, respectively.

\section{Models and Results}

[27] The following model parameters were varied: fault friction, dip angle of the central segment of the Alpine fault, 
creep strength of the crust, shear traction on the bottom of lithosphere, NE boundary condition on the Hikurangi forearc, heat flow and spatial extent of the CVR/TVZ, and interplate shear traction on subduction thrusts. Both nonuniform and uniform heat flow maps were used to help to control the effects of any heat flow error on model selection.

[28] Subduction thrust faults in our model are differentiated by a special limit on the downdip integral of shear traction ("Taumax" of Table 1 ; typically $2.5 \times 10^{12} \mathrm{~N} / \mathrm{m}$ ) imposed on the subduction thrust fault elements [Bird, 1978a]. This corresponds to a shear traction in the subduction zone of $\sim 10 \mathrm{MPa}$ (if the depth range of the subduction shear zone is $\sim 100 \mathrm{~km}$ and subduction dip angle $\sim 30^{\circ}$ ).

[29] More than 90 models have been calculated. As questionable features were discovered, small corrections were made to either the grid file or the programs. Table 1 lists a final set of 76 models and their errors.

\subsection{Models That Test the Strength of Ordinary Faults}

[30] Fault strength has a significant influence on crustal dynamics and strain distribution. We first investigated the hypothesis that the faults in New Zealand are anomalously weak, as in other regions we have studied. Effective fault friction was varied systematically from very weak (0.03) to very strong (0.85). Figure 4 gives model errors as a function of fault friction. The mean errors in stress azimuth, RMS errors in GPS and fault slip rate are plotted individually against the fault friction. Generally, they indicate a consistent preference for low fault friction. It should be noticed that stress direction is not sensitive to fault friction when it exceeds $\sim 0.20$, but stress direction errors become worse for very low values. The combined error indicates that the best models have fault friction of $0.15-0.17$ regardless of the assumed heat flow distribution. Fault friction of 0.17 agrees well with that previously obtained in other Pacific Rim regions (California, Alaska, and Japan).

\subsection{Models With Varying Dip Angle of the Central Alpine Fault}

[31] The dip angle of the central Alpine fault can affect the effective normal stress acting on the fault plane and thus the strike-slip component accommodated by the fault. It has influence on horizontal GPS velocities as well because slip on the downdip extension of the fault will underlie different stations. A published study of gravity anomalies indicates that the central Alpine fault has dip angle of $50^{\circ}-70^{\circ} \mathrm{SE}$ [Woodward, 1979]. Results from half-space modeling of GPS data in the central Southern Alps give nonunique solutions (i.e., $28 \pm 2^{\circ}$ to $39 \pm 14^{\circ}$ for two-fault model; $\sim 48 \pm 2^{\circ}$ for one-fault model) [Beavan et al., 1999]. Initial results from seismic reflection studies in central South Island showed dips of $\sim 40 \pm 5^{\circ}$ [Davey et al., 1995, 1998]. Walcott [1998] reviewed available data sources and argued for a dip around $\sim 50^{\circ}$.

[32] We fixed fault friction at 0.17 and systematically varied the dip angle of the central Alpine fault from $20^{\circ}$ to $90^{\circ}$ for both uniform and nonuniform heat flow. Using nonuniform heat flow, models with intermediate dip angle $50^{\circ}-60^{\circ}$ are preferred as shown in Table 1 and Figure 5. Uniform heat flow models show a preference for angles of $40^{\circ}$ or more but without enough resolution to differentiate a high dip angle from vertical. Only stress direction and GPS data can discriminate among models. This is not surprising as the dip angle of central Alpine fault has little effect on many of our scoring predictions. The greatest effect is on velocity predictions close to the central Alpine fault, which we compare to the central Alps GPS solution [Beavan et al., 1999], and a few most compressive horizontal stress azimuth data derived from focal mechanism. There are only two slip rate data around the central Alpine fault. The available data are not sufficient to completely determine the subsurface geometry of the Alpine fault, but our models support a dip angle of $50^{\circ}-60^{\circ}$ in the central Alpine fault. Based on our modeling results, combined with those previous studies, the dip angle $\sim 50^{\circ}$ is preferred and will be used in the subsequent models.

[33] Models in groups 1, 2, and 3 show that the heat flow map does not significantly affect our choice of the optimal parameters for the overall best models. In the subsequent model groups, we will use only the nonuniform heat flow model of Figure 2, with small variations in North Island.

[34] All models in groups 1, 2, and 3 share similar defects. No extension is predicted in the CVR/TVZ of North Island. The Hikurangi subduction thrust front accommodates almost all plate motion. Offshore faults and the NIDFB are almost locked. These predictions conflict with GPS observations [Beavan and Haines, 2001], geological extension rates in the CVR/TVZ [Wright, 1990], and suggested accommodation styles offshore North Island [Barnes et al., 1998; Beanland, 1995]. Minor adjustments to the model might correct these defects. For example, in the models discussed above we used a fixed (with respect to AU) boundary condition on the northeastern boundary of the Hikurangi forearc, which leaves no freedom for independent movement of boundary and internal forearc nodes. The heat flow $\left(\sim 90 \mathrm{~mW} / \mathrm{m}^{2}\right.$ or uniform $\left.70 \mathrm{~mW} / \mathrm{m}^{2}\right)$ we assumed in groups 1,2 , and 3 may be too low to permit any extension across the CVR/TVZ. It is also possible that the assumed strength difference between the offshore faults and the Hikurangi subduction thrust is incorrect, if the offshore forearc faults are weakened by the same superhydrostatic pore pressure that exists on the subduction shear zone. Therefore, offshore faults might have lower effective friction than the 0.17 we found for most faults in New Zealand. The plate boundary forces imposed by subduction thrusts along the Hikurangi trench clearly influence the local stress equilibrium and the deformation pattern of the Hikurangi arc system; these forces might be too large or too small. These possibilities are considered in model groups 4,5 , and 6 , respectively.

\subsection{Models That Consider Extra Weakening of Faults Offshore North Island}

[35] The extra weakening hypothesis (that faults offshore of North Island are weaker than other thrust faults on land due to superhydrostatic pore pressures) is considered in model group 4. Such excess pore pressures might arise from compaction of subducted sediments and be sustained by continuing accretion and underplating in this fast-moving subduction zone.

[36] The modified grid NZH is used in models H001-007 of group 4. The offshore faults have been treated as being weak as subduction faults. No improvements are observed 


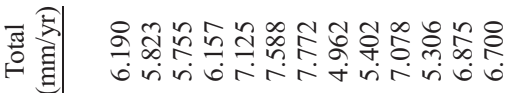

总司

觉完

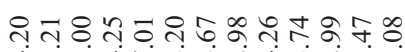

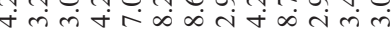

造

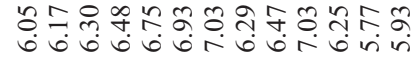

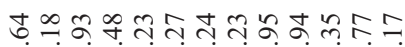

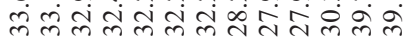

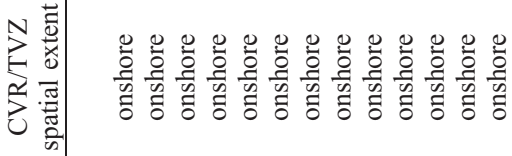

政

密完这

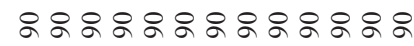

密

趂

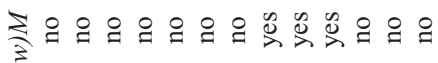

客

产

ठัँ

案

究苍.

胥

$\simeq \simeq \simeq \simeq \simeq \simeq \simeq \simeq \simeq \simeq \simeq \simeq \simeq$

$+++++++++++++$

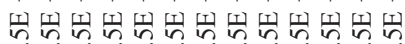

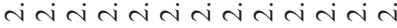

8888888888888

$+4++++++++++$

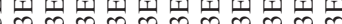

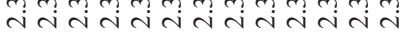

递要

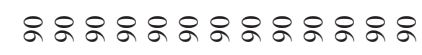

ปิ

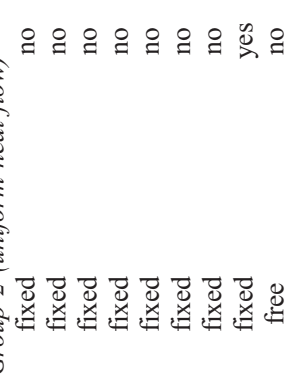

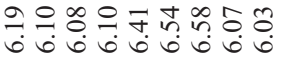

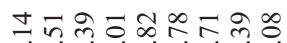

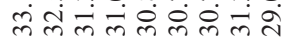

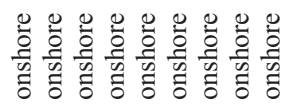

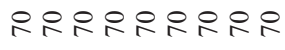

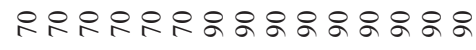

ㅊ๐ㅇ

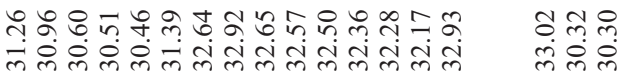

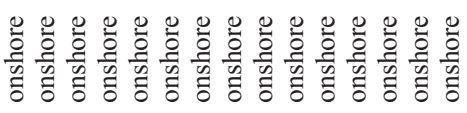

䈉䇏

蓄

害

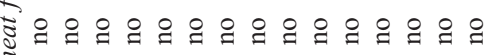
๕๕ ह

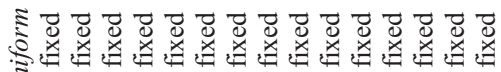

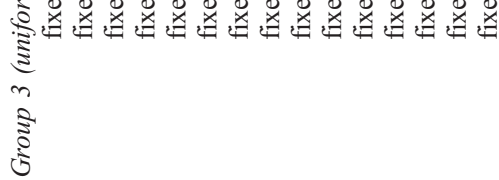

8.88888888

요요요요요요용 $+++++++++++++++$

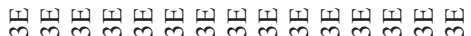

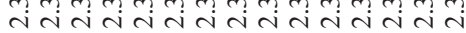

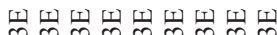

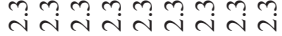

$\simeq \simeq \simeq \simeq \simeq \simeq \simeq$ $++++++++$

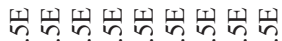
4ง

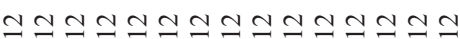
$t+t+t+++++++++$

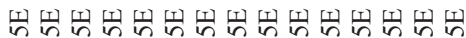

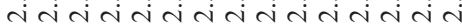<smiles>[CH]1[CH]C1</smiles>
荘

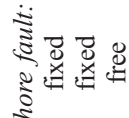
宩 $\frac{1}{3}$ 788 $\overline{2}+++$

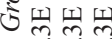
กั่

드 $+++$

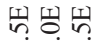
तin

タタタタタタタタタ

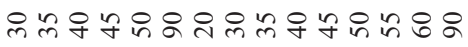
ஃஃஃ

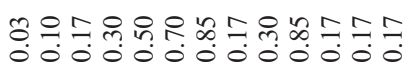

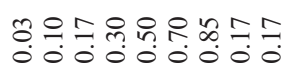

ำำำำำำำำำ

$=\frac{0}{0}=$

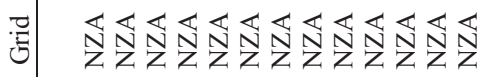
운운운운운운

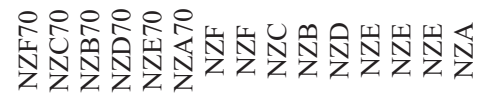

胥忍思 


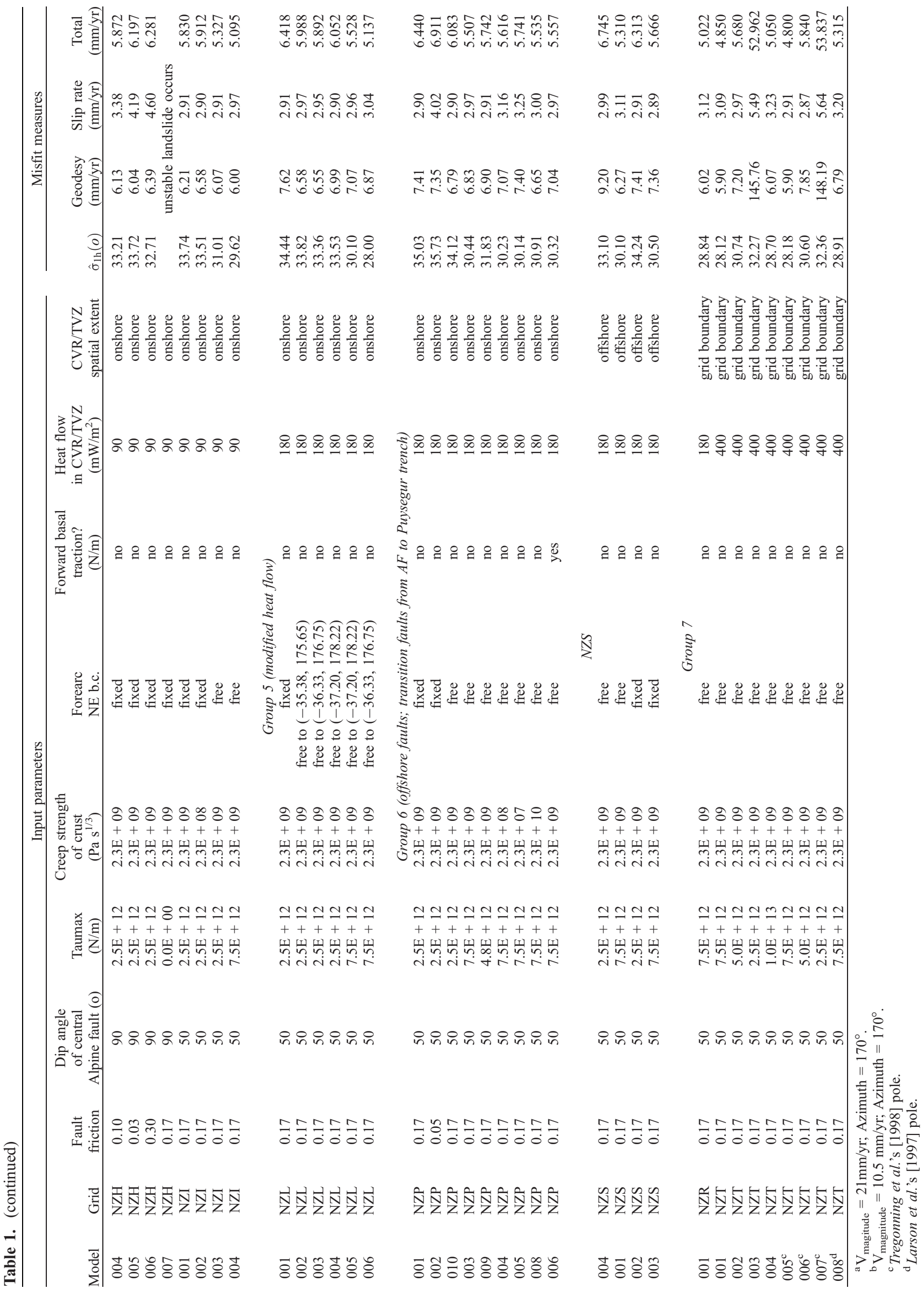


(a)

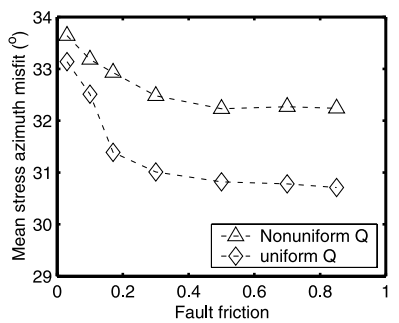

(c)

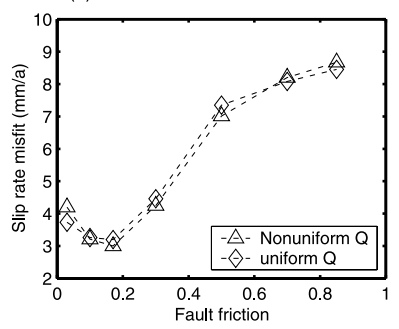

(b)

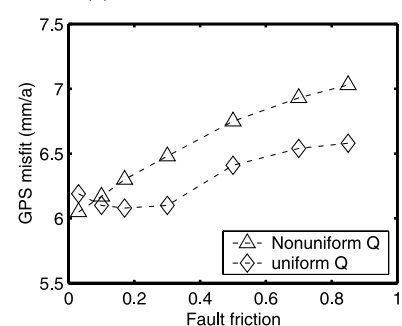

(d)

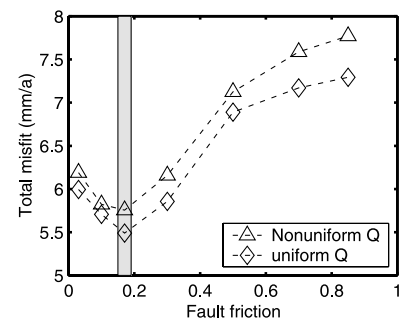

Figure 4. Model scores versus fault friction. Both uniform heat flow $\left(70 \mathrm{~mW} / \mathrm{m}^{2}\right)$ and nonuniform heat flow maps are used. The total misfit error is obtained according to the score formula in the text. The optimal model should give low mean stress azimuth, GPS, and slip rate misfit error. (a) Mean stress azimuth misfit error versus fault friction. Diamond represents uniform heat flow case. Triangle represents nonuniform heat flow case. Same symbol notation is used in (b)-(d). (b) GPS misfit error versus fault friction. (c) Fault slip rate misfit error versus fault friction. (d) Total misfit error versus fault friction. The gray bar indicates compromise values for fault friction.

(Table 1). Other parameters that could affect this defect such as boundary traction force, lower-crustal strength, and the NE boundary condition on the Hikurangi forearc are also varied in this group. The best score in group 4 is achieved in model NZI004, in which ordinary fault friction is 0.17 , and an interplate shear traction force/unit-strike of $7.5 \times 10^{12} \mathrm{~N} /$ $\mathrm{m}$ is assumed for the Hikurangi subduction thrust, and a "free" boundary condition is applied to the Hikurangi forearc. (Here a "free" boundary condition means the boundary is subject only to lithostatic normal tractions but free of shear tractions and anomalous normal tractions). However, we still fail to observe asymmetric extension of CVR and large trench-parallel velocities as suggested by GPS observations [Beavan and Haines, 2001].

\subsection{Models With High Heat Flow in the Central Volcanic Region}

[37] Another possible cause of deficient extension in the CVR/TVZ is that the heat flow $\left(\sim 90 \mathrm{~mW} / \mathrm{m}^{2}\right)$ initially assumed may be too low to allow easy extension. Exceptionally thin crust $(15 \pm 2 \mathrm{~km})$, and low-velocity crust and upper mantle all suggest very high heat flow (to $700 \mathrm{~mW} /$ $\mathrm{m}^{2}$ ) within this area [Stern and Davey, 1987; Bibby et al., 1995]. As we are only interested in large-scale lithosphere structure, a smoothed heat flow map was assumed for the whole Central Volcanic Region in groups 5 and 6. This map has a lower maximum value (180 versus $400 \mathrm{~mW} / \mathrm{m}^{2}$ in group 7) but gives the same total conductive heat flow power. Moreover, this value brings our model crust and

mantle thicknesses (based on steady state conduction) into rough agreement with seismically determined thicknesses [Stern and Davey, 1987]. In model group 7, we also consider models that have heat flow $\sim 400 \mathrm{~mW} / \mathrm{m}^{2}$ concentrated only in the Taupo Volcanic Zone, which is approximately the eastern half of the Central Volcanic Region. All these models show that the high heat flow is necessary for fast extension in the CVR/TVZ, as are appropriate boundary conditions.

\subsection{Models With Variable "Free" Boundary Condition on the Hikurangi Forearc}

[38] The free boundary condition (b.c.) on the northeastern boundary of the Hikurangi forearc proves to be essential for CVR/TVZ extension. Even with very high heat flow, no extension was predicted with a fixed (to AU) boundary condition. This is understandable, as a fixed boundary condition on the NE boundary of the Hikurangi forearc leaves no flexibility for the movement of nodes adjacent to the boundary. Various boundary conditions for the forearc were attempted in model groups 1-6 and a "free" boundary condition seem to be preferred (Figure 6).

[39] Output from models with high heat flow and a "free" northeastern boundary on the Hikurangi forearc correctly predict extension around the CVR/TVZ. But the predicted extension rate is less than $\sim 8 \pm 2 \mathrm{~mm} / \mathrm{yr}$, the extension rate determined from geologic and GPS observations [Wright, 1990; Darby and Meertens, 1995]. This may be caused by inaccurate representation of the northeastern (a)

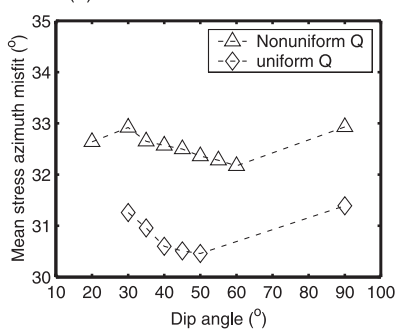

(c)

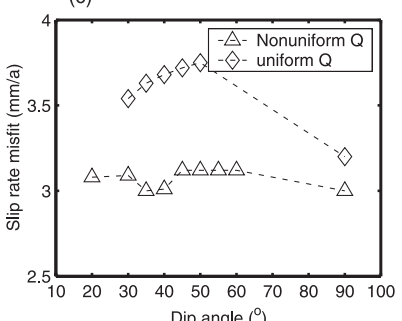

(b)

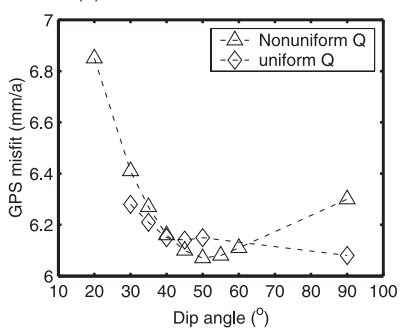

(d)

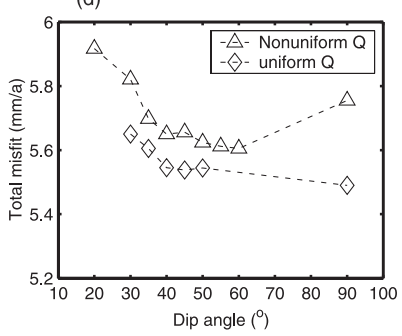

Figure 5. Model scores versus dip angle of central Alpine fault. Both uniform heat flow $\left(70 \mathrm{~mW} / \mathrm{m}^{2}\right)$ and nonuniform heat flow maps are used. The total misfit error is obtained according to the score formula in the text. (a) Mean stress azimuth misfit error versus dip angle of central Alpine fault. (b) GPS misfit error versus dip angle of central Alpine fault. (c) Fault slip rate misfit error versus dip angle of central Alpine fault. (d) Total misfit error versus dip angle of central Alpine fault. Same symbol notation is used as in Figure 4 for (a)-(d), in which diamond and triangle represent uniform heat flow and nonuniform heat flow cases, respectively. 


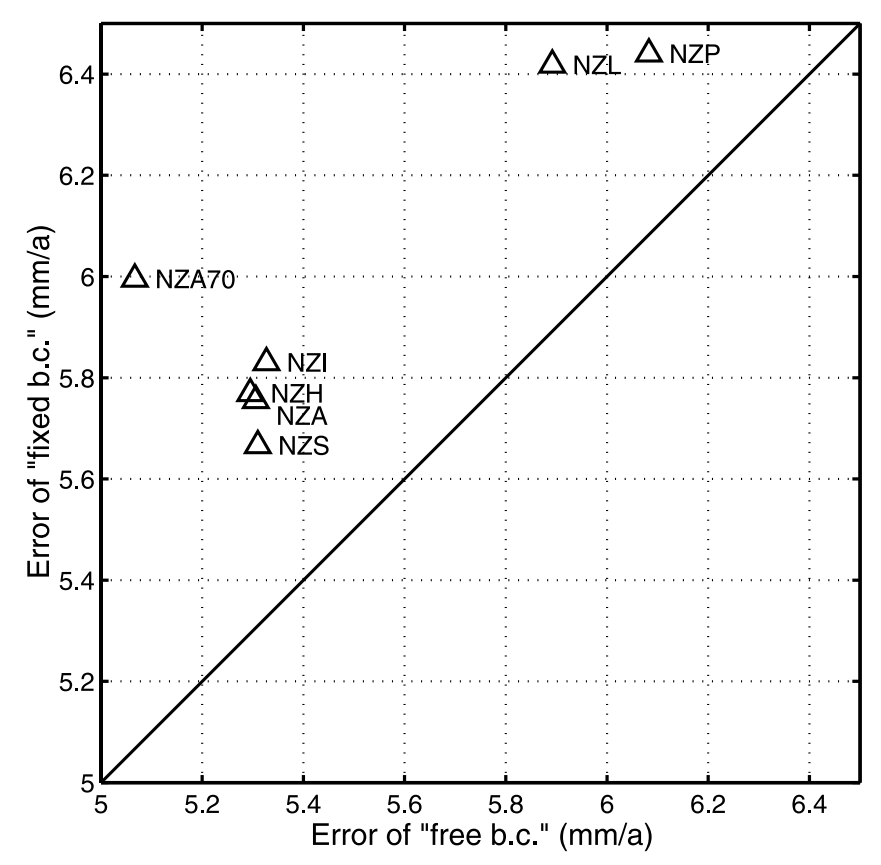

Figure 6. Prediction errors with a fixed northeastern boundary (fixed b.c.) on the Hikurangi forearc versus prediction errors with a "free" boundary condition ("free" b.c.) at the same part of boundary within various model groups. Each triangle corresponds to a pair of models ("free" b.c. and fixed b.c. cases) with the other model parameters being the same. The legend besides each point gives labels of each model pair. The dashed line shows the line on which the different boundary conditions are not differentiable. Generally, models with "free" b.c. on the northeastern boundary of Hikurangi forearc have lower errors and thus are more realistic than models with fixed b.c.

boundary lithospheric pressure, which we do not know exactly. It could also be caused by inaccurate representation of the spatial range of the "free" boundary condition and/or shear tractions imposed by subduction thrusts. Slight modifications to the spatial range of the "free" b.c. and different shear tractions imposed by subduction were combined in model group 5. These small changes in the spatial extent of free b.c. do not change the surface flow field and strain rate distribution very much.

\subsection{Models With Offshore and Transition Faults}

[40] One major feature of our models is the inclusion of all active faults known to us. The best models should be able to give rough slip rate estimates for any buried or inaccessible offshore faults by simulating them. Recent studies show a complicated transition from the south Alpine fault to the purely subducting Puysegur trench [Lebrun et al., 2000]. Also, smooth bathymetric contours and a few large earthquakes on the NW and SE coasts of South Island suggest that they might be bounded by active offshore thrusts (in which case the coastlines represent eroded scarps). The hypothesized offshore faults and a set of transition faults between the strike-slip southern Alpine fault and the Puysegur trench were included in the models of group 6. Offshore mapping suggests a northeastward offshore extension by $\sim 50 \mathrm{~km}$ of the NIDFB and CVR/TVZ normal faults [Lamarche et al., 2000]. As a result the Central Volcanic Region is allowed to extend offshore to White Island volcano in model group 6. The exact offshore extent of the CVR/TVZ is not clear. It may continue to the Lau-Havre Trough back arc spreading center. In model group 7 we investigate this possibility and allow the CVR/TVZ to extend to the northeastern boundary of our model domain. The requirement of a "free" b.c. on the forearc and strong subduction traction forces were further exploited in the group 6. Combinations with other parameters such as reduced crust strength or basal drag were investigated again. (We are concerned that optimization of one new parameter may affect the optimum values of others considered previously.) In general, the best model in this group is NZS001. It successfully predicts some major tectonic features such as back arc extension and trench-parallel flow in the Hikurangi forearc, transpressive partitioning across the Marlborough faults, and complicated slip partitioning at the transition zone of southern South Island.

[41] A few models in previous groups gave better scores than model NZS001, e.g., group2/008/NZA70, group4/ 004/NZI, and group5/006/NZL. We note that these exceptions may arise from the incomplete and nonuniform nature of the scoring data sets. For example, group2/008/ NZA70 gives better scores than group6/001/NZS but it fails to predict any extension within the CVR/TVZ. Moreover, the uniform heat flow assumed in this model has already been shown to be too rough to represent temperatures in New Zealand. Only two GPS benchmarks and a few stress directions exist around the CVR/TVZ, so the model scoring is not very sensitive to extension in the CVR/TVZ. Likewise, group4/004/NZI fails to predict enough extension across the CVR/TVZ. To overcome this problem we rely on the overall score to find a group of "best models" instead of a single optimum. Then other data that could not be quantitatively incorporated into our scoring data sets are used to select from this group. The preferred model should give the best (or near-best) overall score while successfully predicting major features of New Zealand. A more objective approach that depends solely on the overall score to choose the best model will become possible when there are more widespread observations to use for scoring.

\subsection{Models With High Heat Flow Confined to TVZ or Extended to the Model Boundary}

[42] The spatial extent of the CVR/TVZ has significant influence on the predicted extension rate of CVR/TVZ as we saw in Group 6. Models in group 6 that have high heat flow in the Central Volcanic Region and extending offshore to White Island volcano generally predict more extension within the CVR/TVZ than models with high heat flow confined onshore. The CVR/TVZ probably extends offshore at least to $37^{\circ} \mathrm{S}$ instead of being limited within continental crust [Wilson et al., 1995]. Furthermore, extreme heat flows $\left(\sim 400 \mathrm{~mW} / \mathrm{m}^{2}\right)$ concentrate in the Taupo Volcanic Zone [Bibby et al., 1995]. It is interesting to see if expansion of the high heat flow zone to the model boundary and/or concentration of high heat flow in the Taupo Vol- 


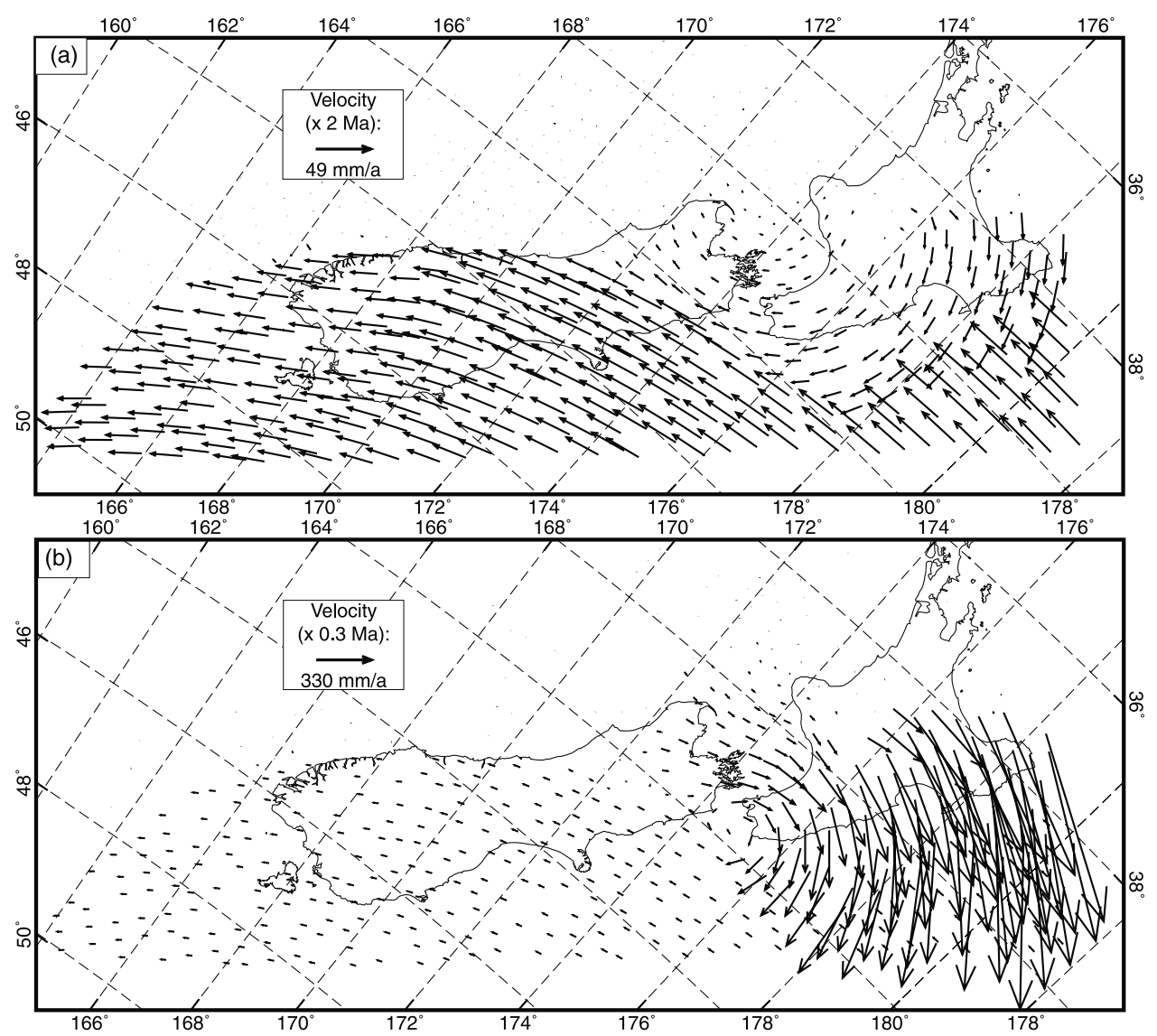

Figure 7. (a) Surface velocity predicted by the preferred model NZT001. (b) Surface velocity of comparison model NZT003. Mercator projection. Both of them use the same parameters: fault friction 0.17 , dip angle in the central Alpine fault $50^{\circ}$, traction "free" boundary condition on the NE boundary of Hikurangi forearc. But the downdip integral of interplate shear traction/unit-strike for model NZT001 $\left(7.5 \times 10^{12} \mathrm{~N} / \mathrm{m}\right)$ is 3 times greater than that assumed in comparison model NZT003. Fast extension resulting from topographic pressure has to be balanced by shear tractions imposed by oblique subduction. To increase legibility, different scaling is used when plotting velocity vectors in (a) and (b).

canic Zone will allow extension to occur more easily. These possibilities are studied in the group 7 with grids NZR and NZT. The preferred model result is NZT001, in which the Taupo Volcanic Zone extends offshore to the model boundary and high heat flow is concentrated within it. Other parameters of this model include effective fault friction of 0.17 , dip of central Alpine fault $\sim 50^{\circ}$, NE boundary condition on the Hikurangi forearc "free," and downdip integral of shear traction of $7.5 \times 10^{12} \mathrm{~N} / \mathrm{m}$ in the Hikurangi subduction thrust. Figure 7 shows the predicted surface velocity in preferred model NZT001 and a comparison model NZT003, which has subduction shear force/unitlength of $2.5 \times 10^{12} \mathrm{~N} / \mathrm{m}$, three times less than $\sim 7.5 \mathrm{E}+$ $12 \mathrm{~N} / \mathrm{m}$ in NZT001. Apparently the topographic pressure arising from hot weak material in the Hikurangi back arc region has to be balanced by shear traction imposed by oblique subduction of Pacific oceanic plate beneath in North Island. Our models show that the concentration of high heat flow to the Taupo Volcanic Zone, eastern part of Central Volcanic Region, does make extension easier. As a result, the slip rate of TVZ normal faults predicted by NZT001 is about $2 \sim 8 \mathrm{~mm} / \mathrm{yr}$ comparing to $1 \sim 3 \mathrm{~mm} / \mathrm{yr}$ in Group6/001/ NZS. Trench-parallel velocities in the Hikurangi forearc increase from $8 \sim 15 \mathrm{~mm} / \mathrm{yr}$ in Group6/001/NZS to $10 \sim 18$ $\mathrm{mm} / \mathrm{yr}$ in NZT001.

\section{8. "Basal Drag" From Lower Mantle Flow?}

[43] One basic question about neotectonics is what forces cause deformation. Important forces on New Zealand include trench suction, isostatic topography forces, and plate boundary shear forces. Additional tractions from lower mantle flow may act on the base of the lithosphere of New Zealand, as we found in previous global and North America models [Bird, 1998; Liu and Bird, 1998]. A "forward" basal drag hypothesis is tested in some models of group 1, 2 , and 6 . We define "forward" basal shear traction as being directed along a plate's velocity with respect to the hot spot (or Africa) reference frame. There is no significant change of the score as well as surface flow for reasonable traction magnitudes 0.5-1.0 MPa. We suspect that the basal drag from mantle flow is probably not important in New Zealand, because it acts on such a limited area.

\subsection{Major Features of the Preferred Model NZT001}

[44] Figure 8 gives predicted strain rates for continuum elements from this model. (This map characterizes the 


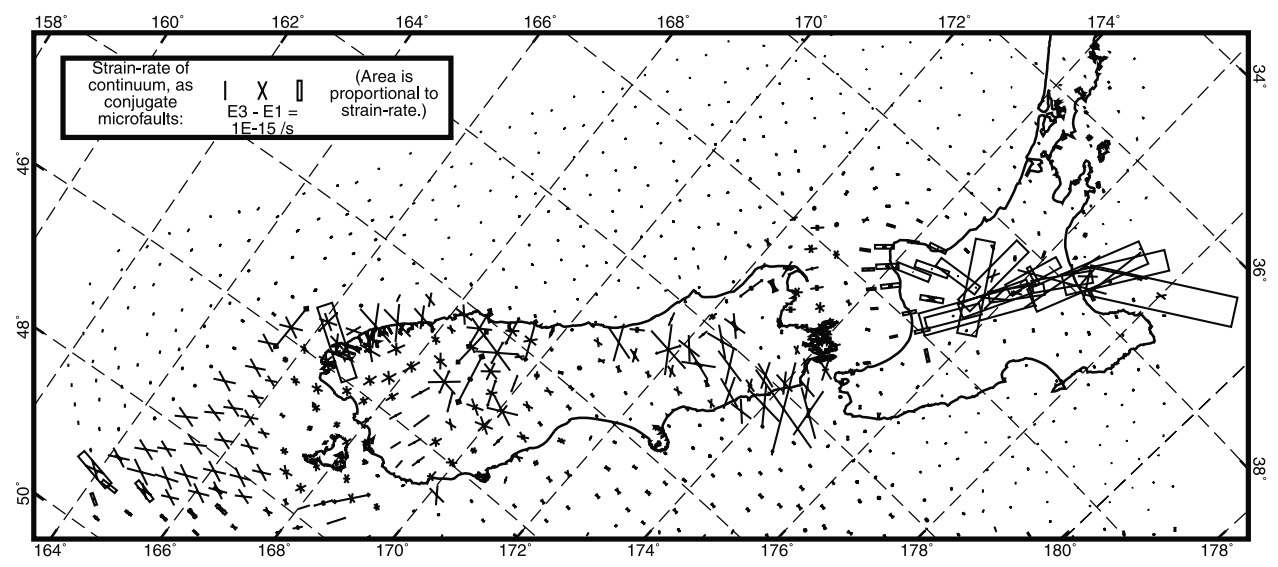

Figure 8. Continuum strain rates (expressed as microfault orientations) from the preferred thin-shell model NZT001. Mercator projection. Dumbbell symbols shows conjugate thrust faulting; X symbols shows conjugate strike-slip faulting; blank rectangles shows conjugate normal faulting. The fault symbols are plotted with area proportional to strain rate. Thinning factor $1 / 7$ is used to reduce the number of symbols and increase legibility.

distributed deformation occurring on faults too small and numerous to appear in our finite element grid, but which were generically represented by our Mohr-Coulomb rheology for cold upper crust.) We predict NNW-SSE extension within the TVZ, E-W and ENE-WSW contraction in NW South Island, high shear strain rates east of the Alpine fault in the Marlborough fault region, high strain rates along the transition between the Alpine fault and Puysegur trench and in the Otago fault-fold belt. Most of these are consistent in location and style with strain rate models obtained from GPS measurements [Beavan and Haines, 2001]. However, we fail to predict shear and contractional strain in southernmost North Island or a strong shear strain belt in the central Southern Alps as observed in the GPS study of Beavan and Haines [2001, Figure 6].

[45] Figure 9 shows predicted most compressive horizontal principal stress directions $\left(\hat{\sigma}_{1 \mathrm{~h}}\right)$ and stress regimes.
Predicted stress regimes include thrust faulting in the Hikurangi subduction region, normal faulting in NE North Island, strike-slip faulting across the Marlborough faults and central South Island, reverse faulting in the NW Nelson and Buller region, complex faulting types within the Fiordland region, and strike-slip faulting in the Puysegur Bank. The stress regimes obtained in our modeling are consistent with results from focal mechanism studies [Doser et al., 1999].

[46] Figure 10 gives long-term average fault slip rates from the preferred model. We have fast back arc extension (average slip rate $\sim 4 \mathrm{~mm} / \mathrm{yr}$ on the eastern bounding normal faults of the TVZ), active faulting in the NW Nelson region, transpressive slip partitioning across the Marlborough faults, and complicated slip partitioning in the transition from the Alpine fault to the Puysegur trench. Most of the relative AU-PA plate motion is accommodated by a plate

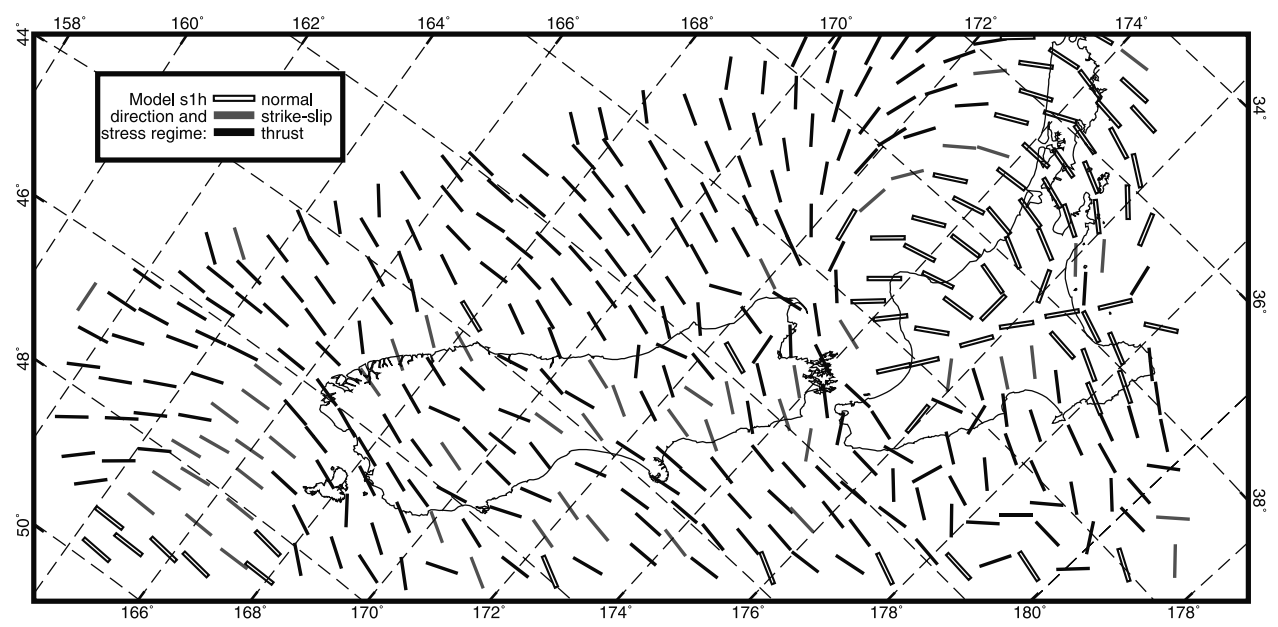

Figure 9. Most compressive horizontal principal stress directions $\left(\hat{\sigma}_{1 h}\right)$ predicted by the best thin-shell model NZT001. Mercator projection. Open rectangle bar represent normal faults, gray bar represent strike-slip faults, and dark filled bar represents thrust faults. Thinning factor $1 / 14$ is used to reduce the number of symbols and increase legibility. 


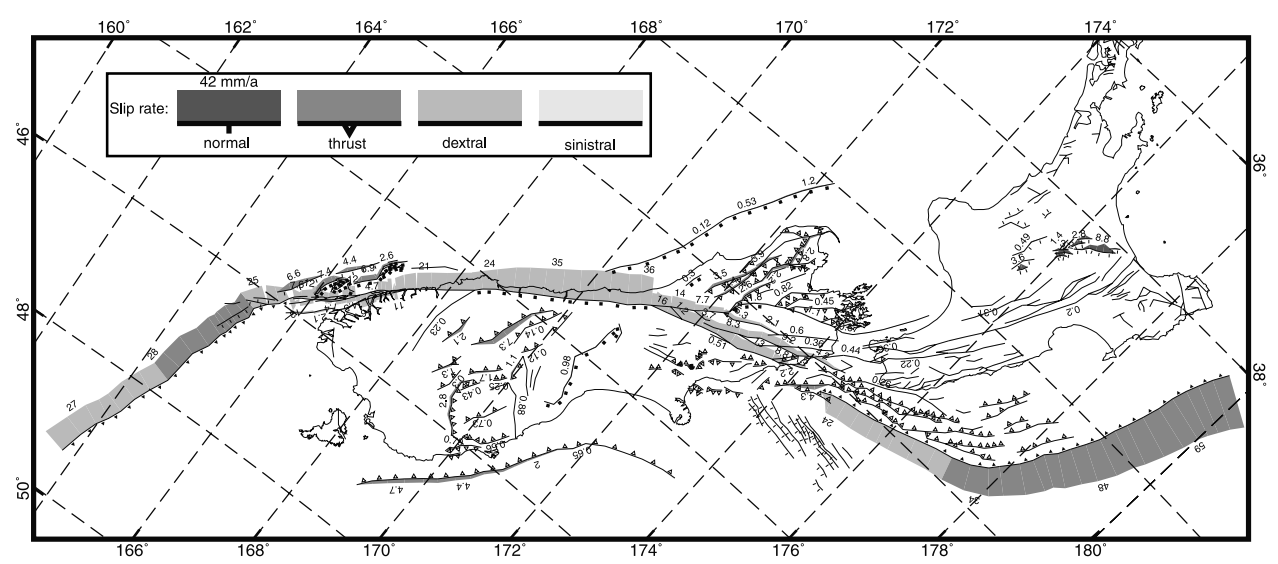

Figure 10. Long-term average fault slip rates predicted by preferred model NZT001. Mercator projection. The width of each ribbon plotted beside a fault is proportional to long-term slip rate, which is also given by numbers in $\mathrm{mm} / \mathrm{yr}$. Faults with very small slip rates are locked and not marked by slip rates in the figure. The different gray scale of ribbon represents normal, thrust, dextral, and sinistral faulting, respectively. In HTML online version, normal, thrust, dextral, and sinistral faulting are represented by the colors of ribbon (yellow, blue, green, or purple).

boundary zone extending from the Alpine fault in South Island to the Hope fault in the Marlborough faults zone, then to the Hikurangi subduction zone offshore from North Island. But we still fail to predict any slip partitioning among faults in southernmost North Island (e.g., Wellington fault, Wairarapa fault etc.), in the NIDFB, or among faults offshore North Island. Most of these are locked even in our preferred model.

\section{Discussion}

\subsection{Fault Strength}

[47] Faults in New Zealand might be thought stronger than faults in other regions, as there is less correlation between fault traces and seismicity [Anderson et al., 1993]. Our models confirm that faults in New Zealand are weak, with effective friction $\sim 0.17$. Faults in New Zealand behave like faults in other tectonically active region such as southern California [Bird and Kong, 1994]. The reasons for lack of correlation between fault traces and surface seismicity could be complicated. One possible explanation is that ductile flow in the lower lithosphere controls the stress state and the accumulation of strain in the upper crust; surface faults might act as local stress and strain modulators but not necessarily localize the earthquake occurrence [Bourne et al., 1998]. Another possibility, which we prefer, is that the instrumental seismic record in New Zealand is too short to give a representative map of seismicity.

[48] Most of our models assume the same fault friction coefficient for all faults in New Zealand (except subduction thrusts). It is possible that fault friction is different on different faults. Major faults with large amounts of slip might be expected to have lower friction (since faults of millimeter slip created in the lab are strong). Our thin-shell modeling could test this slip-weakening hypothesis if we know exactly how much slip has occurred on each fault. However, this information is not yet available. Moreover, our previous modeling work in southern California and western North America has suggested that consideration of slip weakening only slightly improves the fit of our models [Bird and Kong, 1994; Liu and Bird, 1998].

\subsection{Alpine Fault}

[49] Variations in long-term slip rate along the Alpine fault are related to fault segmentation and dip angle. The splay structure in the northern segment of the Alpine fault requires sudden transitions in slip rate along strike (Figure 10). The central Alpine fault is thermally weakened as shown by very high temperatures near the surface $\left(\sim 140^{\circ}-350^{\circ} \mathrm{C}\right.$ at $2 \mathrm{~km}$ depth) and high heat flow [Allis et al., 1979]. Two mechanisms can explain the high temperature gradient in the central Alpine fault: high uplift rate $(\sim 10-17 \mathrm{~mm} / \mathrm{yr})$, and enormous erosion rates $(\sim 2.5-5 \mathrm{~mm} / \mathrm{yr}$ in Miocene-Pliocene and $7-14 \mathrm{~mm} / \mathrm{yr}$ in the Quaternary) due to high precipitation on windward slopes [Wellman, 1979; Allis and Shi, 1995]. Shi et al. [1996] argued that the weakness of the central Alpine fault is not caused by thermal weakening but by effects of decompression along the uplift path and high pore pressures at shallow depth. However, we are concerned that the shortening rate $(\sim 20 \mathrm{~mm} / \mathrm{yr})$ imposed in his model might be too high, and induce excessive crust thickening. A shortening rate of $\sim 10 \mathrm{~mm} / \mathrm{yr}$ seems to be more appropriate [Batt and Braun, 1999]. Possibly, a dynamic instability model can explain the high heat flow and thermal weakening of the central Alpine fault. Continental collision causes crustal thickening and uplift. High erosion at high elevations removes uplifted material, followed by isostatic adjustment of crust. Such adjustment raises midcrustal temperatures close to the surface and results in high heat flow at the surface. This may be the main cause of weak crust in the central Alpine fault. Thermally induced creep may explain the low seismicity in this area.

[50] There is a debate whether the central Alpine fault will fail in future large earthquakes. Walcott [1998] questioned the likelihood of large earthquakes in the central Alpine fault because of possible aseismic creep and its 
shallow brittle-ductile transition depth $(\sim 6 \mathrm{~km})$. However, recent discoveries of prehistoric big earthquakes along the central Alpine fault [Wells et al., 1999], and the absence of evidence for aseismic slip within the Whataroa fault-monitoring network [Beavan et al., 1999] all support the probability of large earthquakes in this area. The long-term average slip rate $(\sim 30 \mathrm{~mm} / \mathrm{yr})$ obtained in our preferred model, combined with other evidence, supports a high probability of large future earthquakes on the central Alpine fault.

\subsection{Offshore Faults to the NW and SE of South Island}

[51] We include hypothesized NW and SE coastal faults along South Island in the models. The locations of these faults were chosen according to the shape of bathymetric contours between Campbell plateau and the South Island continental shelf. The southern part of the SE coastal fault is coincident with the NE part of the Waipounamou fault system, a set of NE-trending en echelon fractures along the shelf edge, confirmed by offshore seismic studies [Carter, 1988, Figure 2]. The traceable Waipounamou faults lie at least from $49^{\circ} \mathrm{S}$ to $\sim 45^{\circ} 50^{\prime} \mathrm{S}$ offshore from Dunedin. The Waipounamou faults are believed to have formed as normal faults, which are now reactivated in transpression [Carter, 1988]. We use a single offshore fault to represent all the Waipounamou faults. Therefore we cannot hope to predict how slip is partitioned among individual faults of the Waipounamou set, but our result gives a first-order estimate of slip accommodated by this fault system. Figure 10 gives predicted long-term slip rates on the hypothesized NW and SE coastal faults of South Island. The predicted slip rate on the SE coastal fault system is up to $4.7 \mathrm{~mm} / \mathrm{yr}$. Since the onshore Akatore fault, the easternmost onshore member of the NE-striking reverse Otago fault-fold belt, has slip rate under $2 \mathrm{~mm} / \mathrm{yr}$ [Litchfield and Norris, 2000], it may not have been the cause of the M4+ events of 1974, 1982, 1989 and 1991 around Dunedin. The offshore faults probably contribute the majority of the local seismic hazard.

\subsection{Central North Island}

[52] One of the intriguing features in North Island is the coexistence of back arc extension with oblique subduction in a very limited area and elevation range. Various hypotheses (not necessarily independent) concerning back arc and forearc extension in North Island have been published, such as gravitational collapse caused by uplift due to underplating, gravitational sliding, and trench suction forces [Darby and Meertens, 1995]. Our models show that the high heat flow of the CVR/TVZ is a crucial factor allowing back arc extension. High heat flow results in anomalously thin crust and mantle lithosphere. Thus the topography is supported by upwelling asthenosphere. The thermally induced buoyancy force associated with asthenospheric upwelling causes excess gravitational potential energy. The contrast with the negative potential energy anomaly of the adjacent trench drives the forearc toward the trench. (However, the motion becomes oblique due to partitioning of the dextral relative motion component between PA and AU.)

[53] Our models confirm that back arc extension is limited by the shear traction in the Hikurangi subduction thrust. The tectonic flow observed on the surface is the joint result of topography-induced flow in the CVR/TVZ, a "free" NE boundary condition on the forearc, and tractions in the Hikurangi subduction thrust.

\subsection{Hikurangi Forearc}

[54] Forearc motion as an independent subplate has been suggested by previous studies in the Tonga and Mariana subduction zones [Bird, 1978b]. Our numerical modeling confirms this concept. Though it is possible that the Kermadec-Tonga Ridge north of New Zealand connects continuously southward to the Hikurangi forearc and forms a continuous Kermadec-Tonga plate sliver, a calculation of the Australia-Tonga pole suggests that extension in the Taupo rift and Havre Trough is not copolar with the Tonga subplate involved in Lau Basin opening to the north of Havre Trough [Zellmer and Taylor, 2001]. The Tonga Ridge likely decomposes into separate slivers east of the Havre Trough and Taupo rift to the south. The combined study of bathymetry, magnetization, GPS measurements, acoustic imagery and seismicity data will help to clarify this problem.

\subsection{Transition From the Southern Alpine Fault to Puysegur Trench}

[55] The complex slip partitioning occurring in the transition zone from the Alpine fault to the Puysegur trench is shown in Figure 10. Most plate motion is predicted to be concentrated on the west branch of the Alpine fault and offshore thrust faults, which is consistent with geological observations [Lebrun et al., 2000]. The net relative velocity across the fault zone is $\sim 24 \mathrm{~mm} / \mathrm{yr}$ or $\sim 80 \%$ of relative plate motion. The remaining $20 \%$ of plate motion is accommodated by diffuse deformation and thrust faulting to the east.

\subsection{Influence of Applied Plate Motion}

[56] The NUVEL-1A Pacific-Australia Euler vector has been chosen for boundary conditions on the southeastern side of the grid. We checked this assumption by repeating the forward calculation using other recently proposed Euler vectors from global space-geodetic data. We use (1) Larson et al.'s [1997] and (2) Tregoning et al.'s [1998] Euler vectors. Four models using Larson et al.'s [1997] pole and Tregoning et al.'s [1998] pole are calculated in model group 7. The resulting velocity fields look quite similar to those from the NUVEL-1A rotation pole. The Tregoning et al.'s pole gives slightly larger parallel velocity component and smaller normal component than NUVEL-1A. But the Larson et al.'s pole gives both larger velocity parallel and normal components than NUVEL-1A. Models using the Tregoning et al.'s pole get the best global score of 4.800 $\mathrm{mm} / \mathrm{yr}$, followed by best score $4.850 \mathrm{~mm} / \mathrm{yr}$ in models using the NUVEL-1A rotation pole. Although the Tregoning et al.'s pole gives the overall best score (in model NZT005), the scores of NZT001 and NZT005 are so close that the two poles are hardly distinguishable in our study. The main differences are a $1 \sim 2 \mathrm{~mm} / \mathrm{yr}$ slip rate increase on the NW Nelson thrust faults and Marlborough faults when the Tregoning et al.'s pole is used. The slip and strain rate fields are hardly changed. To investigate the possible effect of different rotation poles on our choice of optimal parameters, the downdip integral of subduction shear traction is 
systematically varied again using Tregoning et al.'s pole. The results show the same preference for strong subduction traction as using NUVEL-1A.

\subsection{Comparisons of Predicted Long-Term Strain Rate Field With GPS Strain Rate Field}

[57] As shown in Figure 8, the best model NZT001 successfully predicts the major deformation patterns in New Zealand. However, some differences exist between our long-term strain rate map and strain rates derived from GPS studies [Beavan and Haines, 2001]. In northwestern Nelson, our model shows E-W contraction, consistent with GPS results. But we have higher rates of shortening. Holt and Haines [1995] argued that the NW Nelson province does not take up any plate motion, because plate motion is accommodated by the strike-slip structures of the Marlborough region. However, the long-term slip rates of $2-4$ $\mathrm{mm} / \mathrm{yr}$ predicted by our models, combining with the small but significant contractional strain rate, suggests reactivated thrust faults in NW Nelson province are active and have the potential for large thrusting earthquakes.

[58] Along the central Southern Alps, our model does not predict the belt of distributed shear straining seen in GPS studies. Instead our model accommodates most of the plate motion by fault slip. This is because our model gives the long-term average strain rate field, which is averages over many earthquake cycles, while GPS measured strain rates are normally associated with short-term elastic strain accumulation. Another difference between the GPS results and our model prediction is that geodesy shows distributed straining in northern South Island but our model shows a strong concentration of shear strain rates within the eastern Marlborough fault zone. The limited coverage of the strain map by GPS stations may explain this difference [Beavan and Haines, 2001, Figure 2].

[59] In the Wellington region of southern North Island, there is a shear strain rate concentration in the GPS-derived map of Beavan and Haines [2001], which we fail to predict. In our preferred model, no significant strike-slip versus thrust partitioning is observed in the offshore thrust faults and onshore faults between the Hikurangi subduction zone and the northeastern Marlborough fault system. One natural question is why we obtain partitioning along the transition from the Alpine fault to the Puysegur trench while failing to see partitioned slip here. First, such a difference could be caused by differences in unexposed subsurface tearing structures beneath the two transition zones. The AU-PA transform plate boundary began to form in the New Zealand Continental Plateau during the Oligocene. A near-vertical tearing structure in each subducting plate had to form between the subducting plate and the rest of the same plate in order to allow the subduction. The transition zones are above these subsurface discontinuities. It is possible that different subsurface tearing structures cause different strikeslip and thrust partitioning in the two transition zones. Such differences may also relate to fault orientation relative to the plate convergence direction. The sharp arching-up of subducted Australia plate beneath Fiordland and consequently steepening the subducted plate to the north possibly causes plate motion to be transferred upward and partitioned among strike-slip and thrust faults in the overlying plate (R. Reyners et al., Stresses and strains in a twisted sub- duction zone: Fiordland, New Zealand, submitted to Geophysical Journal International, 2001).

[60] Second, our thin-shell method uses the downdip integral of shear traction (plus a lithostatic model of trench topography forces) to approximate the total forces imposed by the subducting Pacific plate on the overlying Australia plate. We did not consider the complex effects of 3-D subsurface fault geometries. How and where the force is exerted along the plate interface may have significant influence on slip partitioning in the overlying plate. To simulate this, 3-D models are clearly needed. Nevertheless, the total force/unit-strike exchanged between the plates has been optimized in our modeling. The Hikurangi forearc block behaves as stress guide due to its very low heat flow $\left(\sim 44 \mathrm{~mW} / \mathrm{m}^{2}\right)$, so forces imposed at its bottom will be transmitted to balance the isostatic topography force from higher elevations in the back arc region. Even though the detailed traction distribution along the interface is not correctly modeled, the total force magnitude derived from force equilibrium will remain the same.

\subsection{Model Limitations}

[61] We used steady state thermal conduction and isostatic equilibrium approximations to infer the crust and mantle lithosphere thicknesses. These approximations are oversimplified. Certainly our model can be improved when more heat flow data and seismic structures are available across New Zealand. Our strategy in forward modeling is to explore the parameter space by varying parameters one at a time to choose the optimal value for that parameter; then to fix it and test another. It is true that under this approach we cannot guarantee our best solution is the global optimum. Fully exploring all possible parameter combinations to find the global minimum solution would require alternative approaches such as a genetic algorithm or Monte Carlo methods. However, we fear that the total number of forward models associated with those methods would be too great to make complete exploration of parameter space computationally feasible at present. As a compromise, we have repeated the optimization of basic parameters like fault friction after each major change in the model.

\section{Conclusion}

[62] Thin-shell models incorporating faults, realistic rheology, laterally varying thermal structure and plate boundary conditions have been applied to simulate the neotectonics of New Zealand. Our modeling confirms that the faults in New Zealand are weak with effective friction $\sim 0.17$, which is consistent with studies of other Pacific Rim regions.

[63] Tectonic deformation in North Island appears to be controlled by topographically induced flow away from the hot volcanic arc, opposed by oblique subduction tractions. The forearc part of the Hikurangi subduction zone appears to act as an independent plate sliver with relative motion with regard to Pacific plate and Australia plate. The determination of the northward extent of this subplate and its rotation pole and rate requires further joint studies.

[64] Long-term average slip rates in the central Alpine fault are about $\sim 30 \mathrm{~mm} / \mathrm{yr}$ with continuous variation along strike. Such rates, combined with prehistoric large earth- 
quakes in the central Alpine fault, strongly suggest the likelihood of large future earthquakes in the area. Strain localization in the fault is clearly related to the thermal weakening arising from anomalously fast uplift and erosion rates in this area.

[65] Our models show very complicated slip partitioning across the transition from the Alpine fault to the Puysegur trench. Average long-term slip rates are predicted for each fault, although they are not yet available from geologic offsets. About $80 \%$ of plate motion is distributed in this fault zone while the rest appears to distribute diffusively to the east. Our results also suggest that the SE coast of South Island could be bounded by an active thrust fault.

[66] Acknowledgments. We thank Terry Webb for providing the New Zealand earthquake catalogue, John Beavan for providing geodetic results, and Peter Molnar for providing a compilation of literature. Z.L. is also grateful for their useful suggestions. Constructive reviews by Tim Dixon, John Beavan, Paul Tregoning, and an anonymous reviewer helped improve an early version of this manuscript considerably. Additional thanks to Martin Reyners for sending a preprint of his paper. This work was supported by the National Science Foundation under grant EAR9902735 to the University of California.

\section{References}

Allis R. G., R. W. Henley, and A. F. Carman, The thermal regime beneath the Southern Alps, in The Origin of the Southern Alps, Bull. R. Soc. N. Z., vol. 18, edited by R. I. Walcott and M. M. Cresswell, pp. 79-85, R. Soc. of N.Z., Wellington, N.Z., 1979.

Allis, R. G., and Y. Shi, New insights to temperature and pressure beneath the central Southern Alps, New Zealand, N. Z. J. Geol. Geophys., 38, 585-592, 1995.

Anderson, H. J., T. Webb, and J. Jackson, Focal mechanisms of large earthquakes in the south island of New Zealand: Implications for the accommodation of Pacific-Australia plate motion, Geophys. J. Int., 115, 1032-1054, 1993.

Barnes, P. M., B. Mercier de Lepinary, J.-Y. Collot, J. Delteil, and J.-C. Audru, Strain partitioning in the transition area between oblique subduction and continental collision, Hikurangi margin, New Zealand, Tectonics, 17, 534-557, 1998.

Batt, G. E., and J. Braun, The tectonic evolution of the Southern Alps, New Zealand: Insights from fully thermally coupled dynamical modelling, Geophys. J. Int., 136, 403-420, 1999.

Beanland, S., The North Island dextral fault belt, Hikurangi subduction margin, New Zealand, unpublished Ph.D. thesis, lodged in the Library, Victoria Univ. of Wellington, Wellington, New Zealand, 1995.

Beanland, S., and J. Haines, The kinematics of active deformation in the North Islands, New Zealand, determined from geological strain rates, N. Z. J. Geol. Geophys., 41, 311-323, 1998.

Beaumont, C., P. Fullsack, and J. Hamilton, Styles of crustal deformation in compressional orogens caused by subduction of the underlying lithosphere, Tectonophysics, 232, 119-132, 1994

Beaumont, C., P. J. J. Kamp, J. Hamilton, and P. Fullsack, The continental collision zone, South Island, New Zealand: Comparison of geodynamical models and observations, J. Geophys. Res., 101, 3333$3359,1996$.

Beavan, J., and H. Haines, Contemporary horizontal velocity and strain rate fields of the Pacific-Australian plate boundary zone through New Zealand, J. Geophys. Res., 106, 741-770, 2001.

Beavan, J., et al., Crustal deformation during 1994-1998 due to oblique continental collision in the central Southern Alps, New Zealand, and implications for seismic potential of the Alpine fault, J. Geophys. Res., 104, 25,233-25,255, 1999.

Berryman K., Active faulting and derived PHS directions in the South Island, New Zealand, in The Origin of the Southern Alps, Bull. R. Soc. N. Z., vol. 18, pg. 29-34, edited by R. I. Walcott and M. M. Cresswell, 1979.

Berryman, K. R., S. Beanland, A. F. Cooper, N. H. Cutten, R. J. Norris, and P. R. Wood, The Alpine fault, New Zealand: Variation in Quaternary structural style and geomorphic expression, Ann. Tecton., Suppl., 6, 126-163, 1992.

Bibby, H. M., T. G. Caldwell, F. J. Davey, and T. H. Webb, Geophysical evidence on the structure of the Taupo Volcanic Zone and its hydrothermal circulation, J. Volcanol. Geotherm. Res., 68, 29-58, 1995.
Bird, P., Finite element modeling of lithosphere deformation: The ZAGROS collision orogeny, Tectonophysics, 50, 307-336, 1978a.

Bird, P., Stress and temperature in subduction shear zones: Tonga and Mariana, Geophys. J. R. Astron. Soc., 55, 411-434, 1978b.

Bird, P., Computer simulations of Alaskan neotectonics, Tectonics, 15, 225-236, 1996

Bird, P., Testing hypothesis on plate-driving mechanisms with global lithosphere models including topography, thermal structure, and faults, J. Geophys. Res., 103, 10,115-10,129, 1998.

Bird, P., Thin-plate and thin-shell finite-element programs for forward dynamic modeling of plate deformation and faulting, Comput. Geosci., 25, $383-394,1999$.

Bird, P., and X. H. Kong, Computer simulations of California tectonics confirm very low strength of major faults, Geol. Soc. Am. Bull., 106, 159-174, 1994.

Bourne, S. J., P. C. England, and B. Parsons, The motion of crustal blocks driven by flow of the lower lithosphere and implications for slip rates of continental strike-slip faults, Nature, 39, 655-659, 1998.

Braun, J., and C. Beaumont, Three-dimensional numerical experiments of strain partitioning at oblique plate boundaries: Implications for contrasting tectonic styles in the southern Coast Ranges, California, and central South Island, New Zealand, J. Geophys. Res., 100, 18,059-18,074, 1995.

Carter, R. M., Post-breakup stratigraphy of the Kaikoura Synthem (Cretaceous-Cenozoic), continental margin, southeastern New Zealand, N. Z. J. Geol. Geophys., 31, 405-429, 1988.

Carter, L., K. B. Lewis, and F. Davey, Faults in Cook Strait and their bearing on the structure of central New Zealand, N. Z. J. Geol. Geophys., 31, 431-446, 1988 .

Cooper, A. F., and R. J. Norris, Anatomy, structural evolution, and slip rate of a plate-boundary thrust: The Alpine fault at Gaunt Creek, Westland, New Zealand, Geol. Soc. Am. Bull., 106, 627-633, 1994.

Cowan, H. A., An evaluation of the late Quaternary displacement and seismic hazard associated with the Hope and Kakapo faults, Amuri district, North Canterbury, M.S. thesis, 241 pp., University of Canterbury, Christchurch, New Zealand, 1989

Darby, D. J., and J. Beavan, Evidence from GPS measurements for contemporary interplate coupling on the southern Hikurangi subduction thrust and for partitioning of strain in the upper plate, Eos Trans. $A G U$, 81, F1126, 2000.

Darby, D. J., and C. M. Meertens, Terrestrial and GPS measurements of deformation across the Taupo Back Arc and Hikurangi forearc regions in New Zealand, J. Geophys. Res., 100, 8221-8232, 1995.

Davey, F. J., T. Henyey, S. Kleffmann, A. Melhuish, D. Okaya, T. A. Stern, and D. J. Woodward, Crustal reflections from the Alpine Fault Zone, South Island, New Zealand, N. Z. J. Geol. Geophys., 38, 601-604, 1995.

Davey, F. J., et al., Preliminary results from a geophysical study across a modern, continent-continent collisional plate boundary: The Southern Alps, New Zealand, Tectonophysics, 288, 221-235, 1998.

DeMets, C., R. G. Gordon, D. F. Argus, and S. Stein, Effects of recent revisions to the geomagnetic reversal time scale on estimates of current plate motions, Geophys. Res. Lett., 21, 2191-2194, 1994.

Doser, D. I., T. H. Webb, and D. E. Maunder, Source parameters of large historical $(1918-1962)$ earthquakes, South Island, New Zealand, Geophys. J. Int., 139, 769-794, 1999.

Funnell, R., D. Chapman, R. Allis, and P. Armstrong, Thermal state of the Taranaki Basin, New Zealand, J. Geophys. Res., 101, 25,197-25,215, 1996.

Holt, W. E., and A. J. Haines, The kinematics of northern South Island, New Zealand, determined from geologic strain rates, J. Geophys. Res., 100, 17,991-18,010, 1995.

Kleffmann, S., F. Davey, A. Melhuish, D. Okaya, T. Stern, and T. S. Team, Crustal structure in the central South Island, New Zealand, from the Lake Pukaki seismic experiment, N. Z. J. Geol. Geophys., 41, 39-49, 1998.

Knuepfer, P. L. K., Estimating ages of later Quaternary stream terraces from analysis of weathering rinds and soils, Geol. Soc. Am. Bull., 100, 12241236,1988

Knuepfer, P. L. K., Temporal variations in latest quaternary slip across the Australian-Pacific Plate boundary, northeastern South Island, New Zealand, Tectonics, 11, 449-464, 1992.

Kong, X., Numerical modeling of the neotectonics of Asia: A new spherical shell finite element methods with faults, Ph.D. dissertation, 227 pp., Univ. of Calif., Los Angeles, Calif., 1995.

Koons, P. O., Two-sided orogen: Collision and erosion from the sandbox to the Southern Alps, New Zealand, Geology, 18, 679-682, 1990.

Koons, P. O., and C. M. Henderson, Geodetic analysis of model oblique collision and comparison to the Southern Alps of New Zealand, N. Z. J. Geol. Geophys., 38, 545-552, 1995. 
Lamarche, G., J. M. Bull, P. M. Barnes, S. K. Taylor, and H. Horgan, Constraining fault growth rates and fault evolution in New Zealand, Eos, 81, 481-486, 2000.

Lamb, S. H., and H. M. Bibby, The last $25 \mathrm{Ma}$ of rotational deformation in part of the New Zealand plate-boundary zone, J. Struct. Geol., 11, 473492, 1989.

Larson, K. M., J. Freymueller, and S. Philipsen, Global plate velocities from the Global Positioning System, J. Geophys. Res., 102, $9961-$ 9981, 1997.

Lensen, G. J., Note on fault correlations across Cook Strait, N. Z. J. Geol. Geophys., 1, 263-268, 1958.

Lebrun, J.-F., G. Lamarche, J.-Y. Collot, and J. Delteil, Abrupt strike-slip fault to subduction transition: The Alpine Fault-Puysegur Trench connection, New Zealand, Tectonics, 19, 688-706, 2000.

Lisowski, M., J. C. Savage, and W. H. Prescott, The velocity field along the San Andreas Fault in central and southern California, J. Geophys. Res., 96, 8369-8389, 1991.

Litchfield, N. J., and R. J. Norris, Holocene motion on the Akatore fault, south Otago coast, New Zealand, N. Z. J. Geol. Geophys., 43, 405-418, 2000.

Little, T. A., R. Grapes, and G. W. Berger, Late Quaternary strike slip on the eastern part of the Awatere fault, South Island, New Zealand, Geol. Soc. Am. Bull., 110, 127-148, 1998.

Liu Z., and P. Bird, Computer simulation of Neotectonics in Latitudes $22^{\circ}-$ $70^{\circ}$, western North America (abstract), Eos Trans. AGU, Fall Meet. Suppl., 79, F566, 1998.

Marson-Pidgeon, K., M. K. Savage, K. Gledhill, and G. Stuart, Seismic anisotropy beneath the lower half of the North Island, New Zealand, J. Geophys. Res., 104, 20,277-20,286, 1999.

Melhuish, A., R. Sutherland, F. J. Davey, and G. Lamarche, Crustal structure and neotectonics of the Puysegur oblique subduction zone, New Zealand, Tectonophysics, 313, 335-362, 1999.

Merzer, A. M., and R. Freund, Transcurrent faults, Beam theory and the Marlborough fault system, New Zealand, Geophys. J. R. Astron. Soc., 38, 553-562, 1974.

Molnar, P., et al., Continuous deformation versus faulting through the continental lithosphere of New Zealand, Science, 286, 516-519, 1999.

New Zealand Geological Survey, Geological map of New Zealand, 1:1,000,000, Dept. of Sci. and Ind. Res., Wellington, New Zealand, 1972.

Norris, R. J., and A. F. Cooper, Origin of small-scale segmentation and transpressional thrusting along the Alpine fault, New Zealand, Geol. Soc. Am. Bull., 107, 231-240, 1995.

Norris, R. J., P. O. Koons, and A. F. Cooper, The obliquely-convergent plate boundary in the South Island of New Zealand: Implications for ancient collision zones, J. Struct. Geol., 12, 715-725, 1990.

Pandey, O. P., Terrestrial heat flow in the North Island of New Zealand, J. Volcanol. Geotherm. Res., 10, 309-316, 1981.

Pettinga, J. R., and D. U. Wise, Paleostress adjacent to the Alpine fault: Broader implications from fault analysis near Nelson, South Island, New Zealand, J. Geophys. Res., 99, 2727-2736, 1994.

Reyners, M., R. Robinson, and P. McGinty, Plate coupling in the northern south island and southernmost north island, New Zealand, as illuminated by earthquake focal mechanisms, J. Geophys. Res., 102, 15,197-15,210, 1997.

Reyners, M., Plate coupling and the hazard of large subduction thrust earthquakes at the Hikurangi subduction zone, New Zealand, N. Z. J. Geol. Geophys., 41, 343-354, 1998.

Savage, J. C., A dislocation model of strain accumulation and release at a subduction zone, J. Geophys. Res., 88, 4984-4996, 1983.

Shi, Y. L., R. Allis, and F. Davey, Thermal modeling of the southern Alps, New Zealand, Pure Appl. Geophys., 146, 469-500, 1996.

Smith, E. G. C., T. Stern, and M. Reyners, Subduction and back-arc activity at the Hikurangi convergent margin, New Zealand, Pure Appl. Geophys., 129, 203-231, 1989.

Stern, T. A., and F. J. Davey, A seismic investigation of the crustal and upper mantle structure within the central volcanic region of New Zealand, N. Z. J. Geol. Geophys., 30, 217-231, 1987.

Stern, T., P. Molnar, D. Okaya, and D. Eberhart-Phillips, Teleseismic P wave delays and modes of shortening the mantle lithosphere beneath South Island, New Zealand, J. Geophys. Res., 105, 21,615-21,631, 2000.

Studt, F. E., and G. E. K. Thompson, Geothermal heat flow in the North island of New Zealand, N. Z. J. Geol. Geophys., 12, 673-683, 1969.

Stirling, M. W., S. G. Wesnousky, and K. R. Berryman, Probabilistic seismic hazard analysis of New Zealand, N. Z. J. Geol. Geophys., 41, $355-$ $375,1998$.
Sutherland, R., Displacement since the Pliocene along the southern section of the Alpine Fault, New Zealand, Geology, 22, 327-330, 1994.

Sutherland, R., and R. J. Norris, Late quaternary displacement rate, paleoseismicity, and geomorphic evolution of the Alpine fault: Evidence from Hokuri Creek, South Westland, New Zealand, N. Z. J. Geol. Geophys., 38, 419-430, 1995.

Townend, J., Estimates of conductive heat flow through bottom-simulating reflectors on the Hikurangi and southwest Fiordland continental margins, New Zealand, Marine Geology, 141, 209-220, 1997.

Townend, J., Heat flow through the west coast, south island, New Zealand, N. Z. J. Geol. Geophys., 42, 21-31, 1999.

Tregoning, P., et al., Determination of current plate motions in Papua New Guinea from Global Positioning System observations, J. Geophys. Res., 103, 12,181-12,205, 1998.

Van Dissen, R. J., Later quaternary faulting in the Kaikoura region, southeastern Marlborough, New Zealand, M.S. thesis, 72 pp., Oregon State Univ., Corvallis, 1989.

Van Dissen, R. J., and R. S. Yeats, Hope fault, Jordan thrust, and uplift of the Seaward Kaikoura Range, New Zealand, Geology, 19, 393-396, 1991.

Vickery, S., and S. Lamb, Large tectonic rotations since the Early Miocene in a convergent plate-boundary zone, South Island, New Zealand, Earth Planet. Sci. Lett., 136, 43-59, 1995.

Walcott, R. I., Modes of oblique compression: Late Cenozoic tectonics of the south island of New Zealand, Rev. Geophys., 36, 1-26, 1998.

Walcott, R. I., D. A. Christoffel, and T. C. Mumme, Bending within the axial tectonic belt of New Zealand in the last $9 \mathrm{Myr}$ from paleomagnetic data, Earth Planet. Sci. Lett., 51, 427-434, 1981.

Wellman H. W., An uplift map for the South Island of New Zealand, and a model for uplift of the Southern Alps, in The Origin of the Southern Alps, Bull. R. Soc. N. Z., vol. 18, edited by R. I. Walcott and M. M. Cresswell, pp. 13-20, R. Soc. of N.Z., Wellington, N.Z., 1979.

Wellman, H. W., and S. Uyeda, New Zealand horizontal kinematics, in Geodynamics of the Western Pacific-Indonesian Region, Geodyn. Ser., vol. 11, edited by T. W. C. Hilde, pp. 423-457, AGU, Washington, D. C., 1983.

Wells, A., M. D. Yetton, and R. P. Duncan, Prehistoric dates of the most recent Alpine fault earthquakes, New Zealand, Geology, 27, 995-999, 1999.

Whitman, D., The isostatic residual gravity anomaly of the Central Andes, $12^{\circ}$ to $29^{\circ} \mathrm{S}$ : A guide to interpreting crustal structure and deeper lithospheric processes, Int. Geol. Rev., 41, 457-475, 1999.

Willett, S. D., Orogeny and orography: The effects of erosion on the structure of mountain belts, J. Geophys. Res., 104, 28,957-28,981, 1999.

Wilson, C. J. N., B. F. Houghton, M. O. Mcwilliams, M. A. Lanphere, S. D. Weaver, and R. M. Briggs, Volcanic and structural evolution of Taupo Volcanic Zone, New Zealand: A review, J. Volcanol. Geotherm. Res., 68, $1-28,1995$

Woodward D. J., The crustal structure of the Southern Alps, New Zealand, as determined by gravity, The Origin of the Southern Alps, Bull. R. Soc. N. Z. vol. 18, edited by R. I. Walcott and M. M. Cresswell, pp. 95-98, R. Soc. of N.Z., Wellington, N.Z., 1979.

Wright, I. C., Late quaternary faulting of the offshore Whakatane Graben, Taupo Volcanic Zone, New Zealand, N. Z. J. Geol. Geophys., 33, 245256, 1990

Yang, J. S., The Kakapo fault: A major active dextral fault in the central North Canterbury-Buller regions of New Zealand, N. Z. J. Geol. Geophys., 34, 137-143, 1991.

Yeats, R. S., and K. R. Berryman, Northern South Island, New Zealand and Transverse Ranges, California: A tectonic comparison (abstract), Geol. Soc. Am. Abstr. Programs, 17, 420, 1985

Yetton, M. D., and D. C. Nobes, Recent vertical offset and near-surface structure of the Alpine fault in Westland, New Zealand, from ground penetrating radar profiling, N. Z. J. Geol. Geophys., 41, 485-492, 1998.

Zellmer, K. E., and B. Taylor, A three-plate kinematic model for Lau Basin opening, $G^{3}$ (Geochemistry, Geophysics, Geosystems Online), 2, 10 May 2001.

P. Bird and Z. Liu, Department of Earth and Space Sciences, University of California, Los Angeles, CA 90095-1567, USA. (pbird@ess.ucla.edu; zliu@ess.ucla.edu) 